\title{
Üstün Yetenekli Çocukların Sosyal Duygusal Gelişimlerine Yönelik Geliştirilen Psiko-Ĕ̆itim Programının Etkisi ${ }^{1}$
}

DOI: 10.26466/opus.931746

\author{
* \\ Seda Sevgili Koçak* - Adnan Kan** \\ ${ }^{*}$ Dr., Söke Bilim ve Sanat Merkezi, Aydın/Türkiye \\ E-Posta: sevgili_seda@hotmail.com \\ ORCID: $\quad$ 0000-0002-8724-0669 \\ **Prof. Dr., Gazi Üniversitesi, Gazi Eğitim Fakültesi, Ankara/Türkiye \\ E-Posta: adnankan@gazi.edu.tr \\ ORCID: $\quad$ 0000-0002-3610-0033
}

\section{Öz}

Bu araştırmanın amacı, üstün yetenekli öğrencilerin sosyal duygusal gelişimlerine yönelik geliştirilen psiko-eğitim programının sosyal duygusal becerilere, yalnızlı̆̆a ve arkadaşlık niteliklerine etkisini incelemektir. 2 deney ve 2 kontrol grubu olmak üzere 32 (3. ve 4. sinrf düzeyi) üstün yetenekli öğrenciyle çalışma grubu oluşturulmuştur. Araştırmada veriler, Sosyal Duygusal Beceri Algısı Ölçeği, Arkadaşlık Niteliği Ölçeği ve Çocuklar İçin Yalnızlık Ölçeği ile elde edilmiştir. Araştırma kapsamında deney gruplarına 8 oturumluk psiko-eğitim programı uygulanmış, kontrol gruplarına ise herhangi bir çalı̧̧ma yapılmamıştır. Araştırma deseni, deney ve kontrol gruplu (öntest, ara ölçüm 1, ara ölçüm 2, ara ölçüm 3, sontest, izleme testi) yarı deneysel bir modeldir. Verilerin analizi için "Mann Whitney U", "Wilcoxon İşaretli Sıralar Testi" ve "Linear Mixed Effects Model" kullanılmış ve sonuçlar SPSS 21 programında analiz edilmiştir. Araştırmadan elde edilen bulgular, uygulanan psiko-eğitim programının deney grubundaki öğrencilerin sosyal duygusal beceri algılarında ve arkadaşlık niteliklerinde artış sağladığı; ancak yalnızlık düzeyinde farklılaşma sağlamadığını ortaya koymuştur. Araştırmadan elde edilen tüm bulgular literatürde bulunan ilgili araştırmalarla tartışılmış ve önerilerde bulunulmuştur.

Anahtar Kelimeler: Üstün Yetenek, Bilim e Sanat Merkezi, Sosyal Duygusal Gelişim, PsikoĔ̆itim Programı, Yalnızlık.

\footnotetext{
${ }^{1}$ Gazi Üniversitesi, Eğitim Bilimleri Enstitü, Rehberlik ve Psikolojik Danışmanlık Bilim Dalı, Üstün yetenekli çocukların sosyal duygusal gelişimlerine yönelik geliştirilen psiko-eğitim programının etkisi isimli tezden üretilmiştir.
} 


\title{
TheEffect of Psycho-Education Program Developed for the Social Emotional Development of Gifted Children
}

*

\begin{abstract}
The objective of this study is to analyse the effects of the psycho-education program developed for the social-emotional development of gifted students on social emotional skills, loneliness and friendship qualities. The study group consisted of 32 ( $3^{\text {rd }}$ and $4^{\text {th }}$ grade levels) gifted students; 2 experimental (16 gifted students) and 2 control (16 gifted students) groups. The data of the research were; "SocialEmotional Ability Perception Scale", "Friendship Quality Scale" and "Loneliness Scale for Children" were collected by applying. Within the scope of the study, 8 sessions of the psycho-education program were applied to the experimental groups and no study was conducted on the control groups. The research design is a quasi-experimental model with experimental and control groups (pre-test, intermediate measurement 1, intermediate measurement 2, and intermediate measurement 3, post-test, follow-up test1). With "Mann Whitney U", "Wilcoxon Signed Sequences Test" and "Linear Mixed Effects Model" were used for the data analysis and the results were analysed in SPSS 21 program. The findings of the study showed that the psycho-education program applied increased the students' perceptions of socialemotional skills and friendship qualities, but did not provide differentiation in loneliness level. All the findings obtained from the research were discussed with relevant researches in the literature and recommendations were made to the application and researchers.
\end{abstract}

Keywords: Gifted, Science and art Center, Social Emotional Development, Psycho-Education Program, Loneliness. 


\section{Giriş}

Üstün yetenekliler, geçmişten günümüze üzerinde yoğunlukla çalışılan bir alan olarak karşımıza çıkmaktadır. Literatürdeki çalışmalarda, üstün yeteneklilik kavramı çeşitli şekillerde tanımlanmıştır. Gagne (2005) üstün yetenekliliği, akranlarına göre sosyal duygusal, psiko-motor ve zihinsel alanların en az birinde yüksek yeteneğe sahip olmakla açılamıştır. BİLSEM Yönergesi'nde (2019) ise üstün yeteneklilik kavramı yerine özel yetenekli birey kavramı ele alınmış ve "yaşıtlarına göre daha hızlı öğrenen; yaratıcılık, sanat, liderliğe ilişkin kapasitede önde olan, özel akademik yeteneğe sahip, soyut fikirleri anlayabilen, ilgi alanlarında bağımsız hareket etmeyi seven ve yüksek düzeyde performans gösteren birey" olarak tanımlanmıştır. Bu tanımlardan görüleceği üzere üstün yetenekli çocukların bazı özellikleri normal gelişim gösteren akranlarına göre farklılık göstermektedir.

Sosyal duygusal gelişim incelendiğinde bireylerin kendini ifade etmesi, duygularını anlaması, tanıması ve düzenlemesi, duygularını ifade etmesi gibi hem olgunlaşma hem de öğrenme sonucu oluşan gelişimsel süreçleri içerdiği görülmektedir (Payton vd., 2000).Sosyal duygusal beceriler; iletişim becerileri, stresle baş etme becerileri, problem çözme becerileri ve benlik saygısını artıran becerileri kapsamaktadır. Elias (2003) iletişim becerilerini mesajları etkin şekilde alma ve iletme, duruma uygun şekilde iletişim sürecini başlatma ve sürdürme, sözlü ve sözsüz iletişimi uygun biçimde anlamayı sağlayan beceriler olarak belirtmiştir. Günlük yaşamda artık sıklıkça yaşanan bir durum olan stresle baş etme becerisi de sosyal duygusal becerilerin içerisinde yer almaktadır. Cüceloğlu (1994, s.321) stresi "bireyin fiziksel ve sosyal çevredeki uyumsuz koşullar nedeniyle, bedensel ve psikolojik sınırlarının ötesinde harcadığı gayret" olarak tanımlamıştır. Çocukluktan itibaren stresle baş etmeye yönelik bazı becerilerin öğretilmesi stresin yaratabileceği olumsuzlukları azaltacaktır. Sosyal duygusal becerilerden bir diğeri problem çözme becerisidir. Problem çözme becerisi, bir hedefe ulaşma sürecinde zorluklarla karşılaşınca bireylerin kullanabileceği duyuşsal, bilişsel ve sosyal beceriler olarak tanımlanabilmektedir (Bingham, 2004). Bu bağlamda sosyal duygusal becerilerin sistematik bir şekilde çocuklara kazandırılması var olan yeteneklerini kullanabilmesi 
ve geliştirilmesi yönünden önem kazanmaktadır (Renzulli, 1999). Özellikle üstün yetenekli çocukların diğer bireylerle daha uyumlu yaşam sürmesi için sosyal duygusal beceriler yaşantılarında oldukça önemli bir yere sahiptir.

Üstün yetenekli çocukların sosyal duygusal gelişimlerine yönelik bazı araştırmalarda, iletişim becerilerinin düşük düzeyde olduğu ve bu nedenle çevresi tarafından dışlanma veya dışlama sorunu ile karşı karşıya kaldığı belirtilmektedir. Bu durumun zekâ puanı arttıkça daha da fazlalaştı̆̆ı vurgulanmaktadır (Özbay ve Palancı, 2011; Stuart ve Beste, 2008). Üstün yetenekli öğrencilerin benlik saygılarına yönelik çalışmalar incelendiğinde; üstün yetenekli çocukların benlik saygılarının düşük olmasını etkileyen bazı etmenler olduğu belirtilmektedir. Bir arada özel eğitim alma (Bildiren, 2018) dışlanma, başarı beklentisi ve etiketlenme bu etmenlerden bazılarıdır. Aynı zamanda üzerinde başarı baskısı hissetmesi hem benlik saygisın hem de stresi etkilemektedir (Peterson, Duncan ve Canady, 2009). Zor hedefler koyma ve ebeveynlerin beklentilerinin yüksek olması da stres durumlarını etkileyen diğer nedenler arasındadır (Dixon, Lapsley ve Hanchon, 2004). Ancak stresle baş etmede kişilerarası ilişkilerde problem çözmeyi öğrenmek önemlidir. Problem çözme becerisinin kazanımı ile var olan stres durumları ile daha iyi baş edebildikleri de belirtilmektedir (Parker ve Asher, 1993).

Sosyal duygusal gelişim kapsamında ele alınan diğer iki önemli konu ise yalnızlık ve arkadaşlık ilişkisidir. Yalnızlık, günümüzde insan yaşamını daha fazla etkileyen bir durum olarak karşımıza çıkmaktadır. Bireylerin ilişkiden doyum alamaması veya düşük düzeyde doyum alması ve ilişki yetersizliği olarak tanımlanmaktadır (Buluş, 1997). Kaiser ve Berndt (1985) özel yetenekli bireylerin sahip oldukları özellikler nedeniyle daha fazla yalnızlık yaşadığını belirtmiştir. Shapiro'ya (2010) göre arkadaşlık akranlarla kurulan karşılıklı ve derin ilişki olarak ifade edilmiştir. Arkadaşlık ilişkileri insan yaşamının her döneminde önemli olmakla birlikte çocukluk döneminde de bazı becerilerin öğrenilmesi açısından oldukça ön plana çıkmaktadır. Ancak üstün yetenekli çocukların farkındalıklarının ve duyarlılıklarının yüksek olması ve zekâ seviyeleri nedeniyle zaman zaman arkadaşlık ilişkilerinde sorun yaşadığı belirtilmektedir. Bu nedenle üstün yetenekli çocukların normal 
gelişim gösteren akranlarına göre sosyal yönden daha fazla problem yaşadıkları öne sürülmektedir(Bickley, 2002).

Bainbridge (2011) tarafından yapılan çalışmada üstün yetenekli çocukların gelişimlerinin eş zamanlı olmaması nedeniyle sosyalduygusal problemlerle karşılaştığı ifade edilmektedir. Bu nedenle üstün yetenekli çocukların sosyal duygusal gelişimlerine yönelik çalışmaların yapılması gerekliliği bazı çalışmalarda vurgulanmıştır (Smutny, 2001). $\mathrm{Bu}$ bağlamda üstün yetenekli çocuklara yönelik eğitim programları geliştirilmekte ve uygulanmaktadır. Literatürdeuygulanan bu psikoeğitim programlarının üstün yetenekli çocuklarınsosyal duygusal gelişimleri üzerinde etkili olduğu belirtilmektedir (Köksal, 2007). Psikoeğitim, bazı becerileri geliştirmek için hazırlanan, ulaşılması planlanan amaçların olduğu ve bu amaçlara yönelik eğitim içeriklerinin sunulduğu süreç olarak tanımlanmaktadır. Psikoeğitim sürecinde bilgi verme, etkileşim ve önleyici çalışmalar yer almaktadır (Güçray, Çekici ve Çolakkadıŏlu, 2009).

Üstün yeteneklilik beraberinde getirdiği olumlu özelliklerle birlikte bazı sorunların temelini de oluşturabilmektedir. Eş zamanlı olmayan gelişimle birlikte özel yetenek alanlarının normal akranlarına göre daha fazla gelişmiş olması sosyal duygusal gelişimlerinde farklılığa neden olmaktadır. Aydın ve Konyalığlu (2011) ise bu süreci üstün yetenekli çocukların hem üstün yetenekliliğin getirdiği riskler hem de gelişimsel dönemlerin sorunlarıyla karşı karşıya kaldığı ile açıklamıştır. Bu bağlamda normal eğitim süreçlerinin yanı sıra özel eğitim desteği de gerekmektedir. Özel eğitim desteğiyle birlikte danışmanlık hizmetlerinde de farklılaştırılmış hizmetlere ihtiyaç duyulmaktadır.

Üstün yetenekli çocukların normal çocuklara göre farklı sosyal duygusal ihtiyaçları olmaktadır. Mevcut araştırmada, üstün yetenekli çocukların sosyal duygusal ihtiyaçlarına yönelik psiko-eğitim programı hazırlanmış ve etkililiği test edilmiştir. Böylece geliştirilen program ile üstün yetenekli çocukların sosyal-duygusal gelişim alanındaki sorunların azalacağı umulmaktadır. Üstün yetenekli çocuklara yönelik hazırlanan psiko-eğitim programı ile bazı becerilerin üstün yetenekli çocuklara kazandırılması amaçlanmıştır. $\mathrm{Bu}$ bağlamda ülkemizin gelişimine katkı sağlayacak bireylerin sosyal-duygusal gelişim alanındaki ihtiyaçları farklılaştırılmış program ile karşılanmaya 
çalış1lacaktır. Bu program ile kendini daha iyi ifade eden bireyler olmayönünde bazı adımlar atılmış olacaktır. Devlet politikaları ile gelişmiş ülkelerde üstün yetenekli çocukların çok yönlü desteklenmeleri mümkündür. Ancak ülkemizde, üstün yetenekli öğrencilere sunulan özel eğitim hizmetinde yoğunlukla zihinsel süreçlere odaklanılmakta ve sosyal ve duygusal gelişimleri geri planda kalmaktadır.

Bilim ve Sanat Merkezi (BİLSEM) için öğrenci tanılamalarının ilkokul birinci sınıfta başlaması üstün yetenekli çocukların erken dönemde tespit edilmesini sağlamaktadır. Bu durum üstün yetenekli çocukların ilkokul dönemlerini kapsayan çalışmaları önemli kılmaktadır. Üstün yetenekliler alanına ilişkin araştırmaların artmasına rağmen uygulamaya dönük deneysel çalışmalar yeterli düzeyde değildir. Bu araştırma ile bu boşluğun doldurulmasına katkı sağlanması umulmaktadır. Aynı zamanda kanıta dayalı uygulamalar açısından da rehberlik ve psikolojik danışma alanını destekleyeceği düşünülmektedir. Ruh sağlığı alanında koruyucu ve önleyici çalışmalar oldukça önemlidir. Bu çalışma ile üstün yetenekli çocukların gelişimsel süreçte yaşayacağı sorunlar odak alınarak koruyucu ve önleyici danışmanlık hizmeti sağlanmış olacaktır. Tüm bunlardan hareketle mevcut araştırmada, üstün yetenekli çocukların sosyal duygusal gelişimlerini konu alan psiko-eğitim programı geliştirmek ve etkisini sınamak amaçlanmaktadır. Bu araştırmada, ana amaca ilişkin daha ayrıntılı bulgular ortaya koymak için araştırmanın denenceleri şöyle tespit edilmiştir:

1. Deney grubundaki üstün yetenekli çocukların sosyal duygusal beceri algısı, yalnızlık düzeyi ve arkadaşlık niteliği sontest puanları kontrol grubundaki üstün yetenekli çocukların sontest puanlarından anlamlı düzeyde yüksektir.

2. Deney grubundaki üstün yetenekli çocukların sosyal duygusal beceri algısı, yalnızlık düzeyi ve arkadaşlık niteliği sontest puanları öntest puanlarından anlamlı düzeyde yüksektir.

3. Deney grubundaki üstün yetenekli çocukların sosyal duygusal beceri algısı, yalnızlık düzeyi ve arkadaşlık niteliği sontest puanları ve izleme testi puanları arasında anlamlı düzeyde fark yoktur.

4. Deney grubundaki üstün yetenekli çocukların iletişim becerileri, problem çözme becerileri, benlik saygısını artıran beceriler ve 
stresle başetme becerileri sontest puanları öntest puanlarından anlamlı düzeyde yüksektir.

5. Deney grubundaki üstün yetenekli çocukların sosyal duygusal beceri algısı tekrarlı ölçüm puanları arasında anlamlı düzeyde fark varken, kontrol grubundaki üstün yetenekli çocukların sosyal duygusal beceri algısı tekrarlı ölçüm puanları arasında anlamlı düzeyde fark yoktur.

\section{Yöntem}

\section{Araştırma Modeli}

Mevcut çalışmada, deney ve kontrol gruplu (öntest, ara ölçüm 1, ara ölçüm 2, ara ölçüm 3, sontest ve izleme testi) yarı deneysel model kullanılmıştır. Araştırmalarda, deneysel desen modelinin gerektirmiş olduğu kontroller sağlanamadığında yarı deneysel modellerden yararlanılmaktadır (Karasar, 2005).

Tablo 1.Araştırma Deseni

\begin{tabular}{|c|c|c|c|c|}
\hline Grup & Öntest & İşlem & Sontest & İzleme \\
\hline & Ölçüm I & & Ölçüm II & Ölçüm III \\
\hline \multirow[t]{3}{*}{ Deney } & *SDBAÖ & Psiko-eğitim uygulaması & *SDBAÖ & *SDBAÖ \\
\hline & *ÇYÖ & *SDBAÖ (3 ara ölçüm) & *ÇYÖ & *ÇYÖ \\
\hline & *ANÖ & & *ANÖ & *ANÖ \\
\hline \multirow[t]{3}{*}{ Kontrol } & *SDBAÖ & *SDBAÖ (3 ara ölçüm) & *SDBAÖ & - \\
\hline & ${ }^{*} C ̧ Y O ̈$ & & ${ }^{*} C ̧ Y O ̈$ & \\
\hline & *ANÖ & & *ANÖ & \\
\hline
\end{tabular}

Tablo 1'de araştırma deseni sunulmuştur. Bu çalışmada, Sosyal Duygusal Beceri Algısı Ölçeği (SDBAÖ), Çocuklar İçin Yalnızlık Ölçeği (ÇYÖ) ve Arkadaşlık Niteliği Ölçeği (ANÖ); programın başında (öntest), program sonunda (sontest) ve program bittikten yaklaşık 5 hafta sonra (izleme) uygulanmıştır. Deney grubuna 8 hafta süren psiko-eğitim programı uygulanmıs, kontrol grubu ile programın sonuna kadar herhangi bir çalışma yapılmamıştır.

Bireylerin zaman içindeki gelişimlerini resmetmek ve grupların gelişim düzeyleri arasındaki farklılıkları görebilmek için 2 hafta arayla 
deney ve kontrol gruplarına "Sosyal Duygusal Beceri Algısı Ölçeği" 3 ara ölçüm olarak uygulanmıştır. Araştırmanın bağımsız değişkeni hazırlanan psiko-eğitim programıdır. Bağımlı değişkeni ise üstün yetenekli öğrencilerin sosyal duygusal beceri algıları, yalnızlık düzeyi ve arkadaş nitelikleridir.

\section{Çalışma Grubu}

Araştırma Aydın ilinde BİLSEM'e devam eden üstün yetenekli öğrencilerle gerçekleştirilmiştir. Deney ve kontrol gruplarının oluşturulmasında dört kriter benimsenmiştir. Dört kriteri aynı anda karşılayan öğrenciler deney ve kontrol gruplarına yansız (seçkisiz) atama yoluyla atanmışlardır. Bu kriterler aşağıda verilmiştir:

1. Sosyal Duygusal Beceri Algısı Ölçeği'nden alınan toplam puana göre ortalamanın altında puan almış olmak.

2. Çocuklar için Yalnızlık Ölçeği'nden alınan toplam puana göre ortalamanın üstünde puan almış olmak.

3. Arkadaşlık Niteliği Ölçeği'nden alınan toplam puana göre ortalamanın altında puan almış olmak.

4. Bu üç kriterin eşleştirilmesi sonucunda belirlenen öğrencilerden araştırmaya katılmaya gönüllü olmak ve ebeveynlerinin izninin olmasi.

Araştırma kapsamında belirlenen ölçekler, 2018-2019 eğitim-öğretim yılında üstün yetenekli öğrencilere uygulanmıştır. Deney ve kontrol gruplarının oluşturulmasında yukarıda belirtilen kriterleri aynı anda sağlayan 40 öğrenci ve ebeveynleri ile görüşme yapılmıştır. Yapılan görüşmeler sonucunda 32 üstün yetenekli öğrenci (16 deney grubu ve 16 kontrol grubu) belirlenmiştir. Üstün yetenekli öğrencilerin zihinsel durumları ve yaşları dikkate alınarak bir grupta en fazla 8 öğrenci olması kararlaştırılmış ve belirlenen deney grubundaki öğrencilerden iki grup oluşturulmuştur.

Deney ve kontrol grubundaki üstün yetenekli çocukların SDBAÖ, ÇYÖ ve ANÖ'den elde edilen öntest puanları arasında istatistiksel olarak anlamlı farklılık olup olmadığı Mann Whitney U testi ile analiz edilmiş ve Tablo 2'de sunulmuştur. 
Tablo 2. SDBAÖ, ÇYÖ ve ANÖ Öntest Puanların Gruba Göre U-Testi Sonucu

\begin{tabular}{lllllll}
\hline & Grup & $\mathbf{n}$ & Sira Ortalaması & Sira Toplamı & U & p \\
\hline SDBAÖ & Deney & 16 & 19,69 & 315,00 & 77,000 &, 054 \\
& Kontrol & 16 & 13,31 & 213,00 & & \\
ÇYÖ & Deney & 16 & 16,19 & 259,00 & 123,000 &, 849 \\
& Kontrol & 16 & 16,81 & 269,00 & & \\
ANÖ & Deney & 16 & 17,16 & 274,50 & 117,500 &, 692 \\
& Kontrol & 16 & 15,84 & 253,50 & & \\
\hline
\end{tabular}

Tablo 2'ye göre deney ve kontrol gruplarında yer alan üstün yetenekli çocukların SDBAÖ $(p>, 05)$, ÇYÖ $(p>, 05)$ ve ANÖ $(p>, 05)$ öntest puanları arasında anlamlı farklılık olmadığı görülmüştür.

Tablo 3' de çalışma grubu özellikleri sunulmuştur.

Tablo 3.Çalışma grubunun demografik bilgileri

\begin{tabular}{llllllll}
\hline Değişkenler & & $\begin{array}{l}\text { Frekans } \\
\text { (f) }\end{array}$ & $\begin{array}{l}\text { Yüzdelik } \\
\text { (\%) }\end{array}$ & Değişkenler & \multicolumn{2}{l}{$\begin{array}{l}\text { Frekans } \\
\text { (f) }\end{array}$} & $\begin{array}{l}\text { Yüzdelik } \\
\text { (\%) }\end{array}$ \\
\hline Yaş & 9 & 16 & 50 & Sınıf düzeyi & 3 & 22 & 68,7 \\
& 10 & 16 & 50 & & 4 & 10 & 31,2 \\
\hline Cinsiyet & Kiz & 15 & 46,9 & Algılanan & Orta & 2 & 6,3 \\
& Erkek & 17 & 53,1 & başarı durumu & Başarılı & 30 & 93,8 \\
\hline BİLSEM & 1 yyl & 6 & 18,8 & Toplam kardeş 1 & 9 & 28,1 \\
süresi & 2 yıl & 21 & 65,6 & sayısı & 2 & 15 & 46,9 \\
& 3 yıl & 5 & 15,6 & & 3 & 8 & 25,0 \\
\hline Toplam & & & & & 32 & 100 \\
\hline
\end{tabular}

Tablo 3'e göre çalışma grubunun 16 's1 \% 50'si 9 yaşında ve $16^{\prime}$ s1 $\% 50$ 'si 10 yaşındadır. 15'i (\%46,9) kız ve 17'si $(\% 53,1)$ erkek öğrencidir. Sınıf düzeyi olarak bakıldığında çalışma grubunun 22'si 3. sınıf $(\% 68,7)$ ve $10^{\prime}$ u $(\% 31,2) 4$. sınıftır. Çalışma grubundaki öğrencilerin 2 'si $(\% 6,3)$ başarı durumu orta olarak algılarken, 30'u (\%93,8) başarılı olarak algılamaktadır. BİLSEM'e 1 yıldır devam eden öğrenci sayısı 6 (\%18,8), 2 yıldır devam eden öğrenci sayısı $21(\% 65,6)$ ve 3 yıldır devam eden öğrenci sayısı ise $5^{\prime}$ dir $(\% 15,6)$. Çalışma grubundaki öğrencilerin 9'u $(\% 28,1)$ tek çocuk, 15'i $(\% 46,9) 2$ kardeş ve 8'i $(\% 25) 3$ kardeştir.

\section{Ölçme Araçları}

Kişisel Bilgi Formu:Öğrencilerin demografik bilgilerini öğrenmek için kişisel bilgi formu araştırmacı tarafından hazırlanmıştır. 
Sosyal Duygusal Beceri Algısı Ölçeği (SDBAÖ): Üstün yetenekli öğrencilerin sosyal duygusal becerilerini ve sosyal duygusal beceriler kapsamında ele alınan; iletişim becerileri, benlik saygısını artıran beceriler, stresle baş etme becerileri ve problem çözme becerilerini tespit etmek için bu ölçme aracı seçilmiştir. Ölçme aracı Baydan (2010) tarafından geliştirilmiştir. Ölçme aracı 3'lü Likert tiptedir. 21 madde ve 4 alt ölçekten oluşmaktadır. Kaiser-Meyer-Olkin (KMO) değeri hesaplanmış ve,917 olduğu bulunmuştur. Bartlett Testi hesaplamaları yapılmış ve anlamlı sonuç elde edilmiştir $(\chi 2=5943,32$, serbestlik derecesi $=780, \mathrm{p}<.001)$. Yapılan açımlayıcı faktör analizi sonucunda madde faktör yüklerinin ,39-,63 arasında değiştiği görülmektedir. Tüm faktörlerin oluşturduğu toplam varyans oranı \%37,412 bulunmuştur. Alınan en düşük puan 21 en yüksek puan ise 63'dür. Ölçme aracından alınan yüksek puan sosyal duygusal becerilerin iyi olduğunu, düşük puan ise sosyal duygusal becerilerin geride olduğunu göstermektedir (Baydan, 2010).

Çocuklar İçin Yalnızlık Ölçeği (ÇYÖ): Üstün yetenekli çocukların yalnızlık düzeylerini belirlemek için kullanılan ölçme aracıdır. Ölçme aracı üstün yetenekli çocukların yalnızlık düzeyini ölçmektedir. 3-4 sinıflar için oluşturulan formda 19 madde bulunmaktadır. Ölçme aracı Asher ve Wheeler (1985) tarafından geliştirilmiş ve Kaya (2005) tarafından Türkçeye uyarlanmıştır. Faktör analizi yapılmadan önce, verilerin faktör analizine uygunluğu $\mathrm{KMO}$ ve Bartlett testi ile sınanmış ve verilerin faktör analizi için uygun olduğu görülmüştür $(n=553$, $\mathrm{KMO}=.92$, Bartlett testi sonucu 2179,64, $\mathrm{p}<$,01). Faktör yüklerinin ,30 ile ,78 arasında değiştiği gözlenmiştir. Yapılan geçerlik ve güvenirlik çalışmaları sonucunda iç tutarlık katsayısı, 87 ve test tekrar test yöntemi ile hesaplanan güvenirlik katsayısı ise ,76 olarak hesaplanmıştır. Ölçme aracı, 5'li likert tipi ölçektir. Ölçekten alınabilecek en az puan 11 en yüksek puan ise $55^{\prime}$ dir (Kaya, 2005).

Arkadaşlık Niteliği Ölçeği (ANÖ): Üstün yetenekli çocukların arkadaşlık niteliklerinin nasıl olduğunu görmek amacıyla kullanılmıştır. Parker ve Asher (1993) tarafından geliştirilmiş ve Öztürk (2016) tarafından Türkçe'ye uyarlanmıştır. Ölçeğin, yapı geçerliğini incelemek amacıyla 
açımlayıcı faktör analizi ve doğrulayıcı faktör analizi yapılmıştır. Açımlayıcı Faktör Analizi sonucunda 6 faktörlü bir yapı elde edilmiştir. Bu yapı toplam varyansın \% 50,84'sini açıklamıştır. Yapılan DFA'da elde edilen modelin uyum indeksleri incelenmiştir. Kikare değerinin $\left(x^{2}=1067,89, N=703, p=0,00\right)$ anlamlı olduğu görülmüştür. Araştırmada, iç tutarlılık katsayısı ölçeğin tümü için ,89dur. Ölçek 5'li likert tipindedir. Ölçekten alınabilecek en yüksek puan 132'dir. Ölçekten alınan yüksek puan üstün yetenekli çocukların arkadaşlık niteliklerinin iyi olduğunu göstermektedir. Mevcut araştırmanın amacına uygun olarak bu ölçeğin toplam puanı esas alınmıştır (Öztürk, 2016).

\section{Verilerin Toplanması}

Verilerin toplanması sürecinde, etik onay (Gazi Üniversitesi, 11.01.2019) ve resmi izinler (Aydın Valiliği ve Aydın Milli Eğitim Müdürlüğü, 19.02.2019) alındıktan sonra üstün yetenekli öğrencilere SDBAÖ, ÇYÖ ve ANÖ uygulanmıştır. Sosyal duygusal gelişime yönelik psiko-eğitim programı uygulama sürecinde, iki hafta arayla SDBAÖ ara değerlendirmeler için çalışma grubuna 3 defa daha uygulanmıştır. Programın 8 hafta olması ve 3 ara ölçüm alınması nedeniyle uygulama aralıklarının eşit aralıklı olacak şekilde ve 2 hafta arayla yapılmasına karar verilmiştir. Program uygulama sonrasında sontest ve yaklaşık 5 hafta sonra izleme testi uygulanmıştır.

\section{Verilerin Analizi}

Elde edilen veriler üzerinde SPSS 21 kullanılarak çözümleme yapılmıştır. Verilerin dağılım koşulları ve çalışma grubunun sayısı nedeniyle parametrik olmayan istatistik tekniklerinden yararlanılmıştır. Deney ve kontrol grubunun öntest, sontest ve izleme puanları arasındaki farkı incelemek için $(\mathrm{p}<, 05)$ Mann Whitney U Testi; ilişkili ikili ölçümlerde Wilcoxon İşaretli Sıralar Testi kullanılmıştır. Tekrarlı ölçümlerin analizi öncesinde bilgi kriterleri incelenmiş ve uygunluğuna bakılmıştır. Bilgi kriterleri değerlerine tablo 4 'te yer verilmiştir. 
Tablo 4. Bilgi Kriteri Dĕ̆erleri

\begin{tabular}{llllll}
\hline & $\begin{array}{l}\text { Benlik } \\
\text { Saygısı }\end{array}$ & $\begin{array}{l}\text { İletişim } \\
\text { Becerileri }\end{array}$ & $\begin{array}{l}\text { Problem } \\
\text { Çözme }\end{array}$ & $\begin{array}{l}\text { Stresle Baş } \\
\text { etme }\end{array}$ & Toplam Puan \\
\hline Akaike's Bilgi Kriteri (AIC) & 316,860 & 337,528 & 363,030 & 337,926 & 530,889 \\
HurvichandTsai's (AICC) & 316,995 & 337,663 & 363,164 & 338,061 & 531,024 \\
Bozdogan's (CAIC) & 323,904 & 344,571 & 370,073 & 344,969 & 537,933 \\
Schwarz'sBayesian (BIC) & 321,904 & 342,571 & 368,073 & 342,969 & 535,933 \\
\hline
\end{tabular}

Tablo 4'te sunulan bilgi kriteri değerleri incelenmiş ve sonrasında tekrarlı ölçümlere dayalı "Linear Mixed Effects Model" analizleri yapılmıştır.

\section{Üstün Yetenekli Öğrencilere Yönelik Hazırlanan Psiko-Eğitim Programı:} Hazırlanan bu programla üstün yetenekli çocukların sosyal duygusal becerilerinin, arkadaşlık niteliklerinin artması ve yalnızlık düzeylerinin düşmesi amaçlanmıştır. Programda temel psikolojik danışma ilkeleri ve grup yapılandırma gereklilikleri dikkate alınmıştır. Program 8 oturum, haftada bir kez ve ortalama 40 dakikalık oturumlar şeklinde planlanmıştır. Programın oturum başlıklarına Tablo 5'te yer verilmiştir:

Tablo 5. Programın Oturum Başlıkları

\begin{tabular}{llll}
\hline 1. Oturum & Gel Tanışalım & 5. Oturum & Duygularım ve Ben \\
\hline 2. Oturum & Gel Konuşalım & 6. Oturum & Duygulandım \\
\hline 3. Oturum & Ben Kimim & 7. Oturum & Rengârenk \\
\hline 4. Oturum & Güçlü ve Zayıf Dinozor & 8. Oturum & $\begin{array}{l}\text { Sorumluluğumu Alıyorum ve } \\
\text { Gülümsüyorum }\end{array}$ \\
\hline
\end{tabular}

Program geliştirildikten sonra üç uzman görüşüne sunulmuştur. Bu uzmanlar seçilirken; eğitim alanında olmasına, program geliştirmeye hâkim olmasına, ele alınan değişkenlerle çalışmış olmasına, üstün yetenekli çocuklara yönelik deneyimleri olmasına dikkat edilmiştir. "Uzman Değerlendirme Formu" aracılığıyla değerlendirmeler alınmış ve dönütlere uygun şekilde güncellemeler yapılmıştır. Uzmanlardan alınan son görüşlerin uygunluğuna bakılmış ve uzman değerlendirmeleri arasındaki tutarlılığın \%100 olduğu tespit edilmiştir. Tutarlılık hesaplanırken, Güvenirlik = Görüş Birliği / (Görüş Birliği + Görüş Ayrılığı) formülü kullanılmıştır (Miles ve Huberman, 1994). Programın oturum özetleri ekte sunulmuştur. 


\section{Bulgular}

Deney grubundaki üstün yetenekli çocuklarn sosyal duygusal beceri algısı, yalnızlık düzeyi ve arkadaşlık niteliği sontest puanlarn kontrol grubundaki üstün yetenekli çocuklarn sontest puanlarından anlaml düzeyde yüksektir: Deney ve kontrol grubu SDBAÖ, ÇYÖ ve ANÖ sontest puanları arasında istatistiksel olarak anlamlı düzeyde farklılık olup olmadığı Mann Whitney $U$ testi ile analiz edilmiş ve Tablo 6'da sunulmuştur.

Tablo 6. SDBAÖ, ÇYÖ ve ANÖ Sontest Puanlarn Gruba Göre U-Testi Sonucu

\begin{tabular}{|c|c|c|c|c|c|c|}
\hline & Grup & $\mathbf{n}$ & Sira Ortalaması & Sira Toplamı & $\mathrm{U}$ & $\mathbf{P}$ \\
\hline \multirow[t]{2}{*}{ SDBAÖ } & Deney & 16 & 20,31 & 325,00 & 67,00 &, $021^{*}$ \\
\hline & Kontrol & 16 & 12,69 & 203,00 & & \\
\hline \multirow[t]{2}{*}{ ÇYÖ } & Deney & 16 & 15,38 & 246,00 & 110,00 & 496 \\
\hline & Kontrol & 16 & 17,63 & 282,00 & & \\
\hline \multirow[t]{2}{*}{ ANÖ } & Deney & 16 & 19,78 & 316,50 & 75,50 & $048^{*}$ \\
\hline & Kontrol & 16 & 13,22 & 211,50 & & \\
\hline
\end{tabular}

${ }^{*} p<, 05$

Tablo 6'ya göre deney ve kontrol grubundaki üstün yetenekli çocukların SDBAÖ $(\mathrm{p}<, 05)$ ve ANÖ $(\mathrm{p}<, 05)$ sontest puanları arasında anlamlı farklılık var iken, ÇYÖ $(p>, 05)$ sontest puanları arasında anlamlı düzeyde farklılık olmadığı görülmüştür. Bu bulguya göre psiko-eğitim programının sonunda deney grubundaki üstün yetenekli öğrencilerin sosyal duygusal becerileri ve arkadaşlık nitelikleri kontrol grubundaki öğrencilere göre artış gösterirken yalnızlık düzeylerinin artış göstermediği söylenebilir.

Gruplar arası ortalama puanlardaki farkın değerlendirilebilmesi için hesaplanan etki büyüklüğü sosyal duygusal beceri algısı için $\mathrm{d}=.10$, arkadaşlık niteliği için $\mathrm{d}=.08$ ve yalnızlık düzeyi için $\mathrm{d}=.03$ bulunmuştur. Cohen (1988) etki büyüklügüunü, d değeri .2'den küçük olduğunda zayıf, .5 olduğunda orta ve .8 'den büyük olduğunda ise kuvvetli olarak yorumlamıştır.

Deney grubundaki üstün yetenekli çocuklarn sosyal duygusal beceri algısı, yalnızlı düzeyi ve arkadaşlık niteliği sontest puanları öntest puanlarından anlamlı düzeyde yüksektir: Deney grubu SDBAÖ, ÇYÖ ve 
ANÖ öntest ve sontest puanları arasında istatistiksel olarak anlamlı düzeyde farklılık olup olmadığı Wilcoxon İşaretli Sıralar Testi ile analiz edilmiş ve Tablo 7'de sunulmuştur.

Tablo 7. Öntest ve Sontest Puanlarına İlişkin Wilcoxon İşaretli Stralar Testi Sonuçları

\begin{tabular}{lllllll}
\hline & Öntest-Sontest & $\mathbf{n}$ & Sira Ortalaması & Sira Toplamı & $\mathbf{z}$ & $\mathbf{P}$ \\
\hline SDBAÖ & Negatif & 0 &, 00 &, 00 & $-3,415$ &, $001^{*}$ \\
& Pozitif & 15 & 8,00 & 120,00 & & \\
& Eşit & 1 & & & & \\
\hline ÇYÖ & Negatif & 7 & 5,43 & 38,00 &,- 526 &, 599 \\
& Pozitif & 6 & 8,83 & 53,00 & & \\
& Eşit & 3 & & & $-2,134$ &, $033^{*}$ \\
& Negatif & 4 & 5,63 & 22,50 & & \\
& Pozitif & 11 & 8,86 & 97,50 & & \\
& Eşit & 1 & & & & \\
\end{tabular}

${ }^{*} p<, 05$

Tablo 7'ye göre deney grubunun SDBAÖ $(p<, 05)$ ve ANÖ $(p<, 05)$ öntest ve sontest puanları arasında anlamlı farklılık var iken ÇYÖ $(p>, 05)$ öntest ve sontest puanları arasında anlamlı farklılık olmadığı görülmüştür. Bu bulguya göre uygulanan program aracılığıyla deney grubundaki üstün yetenekli öğrencilerin sosyal duygusal becerileri ve arkadaşlık niteliklerinin artış gösterdiği, yalnızlık düzeylerinde ise farklılık olmadığı söylenebilir.

Deney grubundaki üstün yetenekli çocukların sosyal duygusal beceri algısı, yalnızlık düzeyi ve arkadaşlık niteliği sontest puanları ve izleme testi puanları arasında anlamlı düzeyde fark yoktur: Deney grubundaki üstün yetenekli çocukların SDBAÖ, ÇYÖ ve ANÖ sontest ve izleme testi puanları arasında istatistiksel olarak anlamlı düzeyde farklılık olup olmadığ1 Wilcoxon İşaretli Sıralar Testi ile analiz edilmiş ve Tablo 8' de sunulmuştur.

Tablo 8. Deney Grubu Sontest ve İzleme Testi Puanlarına İlişkin Wilcoxon İşaretli Stralar Testi Sonuçları

\begin{tabular}{lllllll}
\hline & Sontest-İzleme & $\mathbf{n}$ & Sıra Ortalaması & Sira Toplamı & $\mathbf{z}$ & P \\
\hline SDBAÖ & Negatif & 8 & 8,06 & 64,50 &,- 259 &, 796 \\
& Pozitif & 7 & 7,93 & 55,50 & & \\
& Eşit & 1 & & & & \\
& Negatif & 23 & 17,41 & 400,50 & $-3,960$ &, $000^{*}$ \\
\hline ÇYÖ & & & &
\end{tabular}




\begin{tabular}{llllllll}
\hline & Pozitif & 6 & 5,75 & & 34,40 & & \\
& Eşit & 3 & & & & \\
\hline ANÖ & Negatif & 9 & 8,56 & 77,00 & &, 333 \\
& Pozitif & 6 & 7,17 & 43,00 & & \\
& Eşit & 1 & & & & \\
\hline
\end{tabular}

${ }^{*} p<, 05$

Tablo 8'e göre deney grubunun SDBAÖ $(p>, 05)$ ve ANÖ $(p>, 05)$ sontest ve izleme puanları arasında anlamlı farklılık yok iken Çocuklar İçin Yalnızlık Ölçeği $(p<, 05)$ sontest ve izleme puanları arasında anlamlı farklılık olduğu görülmüştür. Bu bulgu, uygulanan psiko-eğitim programının sosyal duygusal beceriler ve arkadaşlık niteliği üzerindeki etkisinin kalıcı olduğu şeklinde yorumlanabilir. Deney grubundaki üstün yetenekli öğrencilerin programin bitiminden 5 hafta sonra yalnızlık düzeyinin düştüğü ve uygulanan programın yalnızlığa etkisinin belli bir süre sonra gözlemlendiği belirtilebilir.

Deney grubundaki üstün yetenekli çocuklarn iletişim becerileri, problem çözme becerileri, benlik saygısını artıran beceriler ve stresle başetme becerileri sontest puanlar öntest puanlarndan anlaml düzeyde yïksektir:

Tablo 9.Deney Grubunun SDBAÖ Alt Boyutları Puanlarna İlişkin Öntest- Sontest Wilcoxon İşaretli Stralar Testi Sonuçları

\begin{tabular}{|c|c|c|c|c|c|c|}
\hline Alt Boyutlar & Öntest- Sontest & $\mathbf{n}$ & Sira Ortalaması & Sira Toplamı & $\mathbf{z}$ & $\mathrm{p}$ \\
\hline \multirow[t]{3}{*}{ İletişim Becerileri } & Negatif & 1 & 4,00 & 4,00 & $-3,222$ & $001^{*}$ \\
\hline & Pozitif & 14 & 8,29 & 116,00 & & \\
\hline & Eşit & 1 & & & & \\
\hline \multicolumn{2}{|c|}{ Benlik Saygısını ArtıranNegatif } & 2 & 2,50 & 5,00 & $-2,099$ & $036^{*}$ \\
\hline \multirow[t]{2}{*}{ Beceriler } & Pozitif & 7 & 5,71 & 40,00 & & \\
\hline & Eşit & 7 & & & & \\
\hline Problem Çözme & Negatif & 3 & 4,00 & 12,00 & $-2,364$ & , $018^{*}$ \\
\hline \multirow[t]{2}{*}{ Becerileri } & Pozitif & 10 & 7,90 & 79,00 & & \\
\hline & Eşit & 3 & & & & \\
\hline \multirow{3}{*}{$\begin{array}{l}\text { Stresle Baş Etme } \\
\text { Becerileri }\end{array}$} & Negatif & 2 & 7,00 & 14,00 & $-2,223$ & $026^{*}$ \\
\hline & $\overline{\text { Pozitif }}$ & 11 & 7,00 & 77,00 & & \\
\hline & Eşit & 3 & & & & \\
\hline
\end{tabular}

${ }^{*} p<, 05$

Tablo 9'a göre deney grubunun iletişim becerileri, benlik saygısını artıran becerileri, problem çözme becerileri ve stresle baş etme becerileri 
$(\mathrm{p}<, 05)$ öntest ve sontest puanları arasında anlamlı farklılık olduğu görülmüştür. $\mathrm{Bu}$ bulguya göre deney grubundaki üstün yetenekli öğrencilerin sosyal duygusal beceri alt boyutlarının program öncesine göre program sonunda yükseldiği söylenebilir.

\section{Tekrarlı Ölçümlere Yönelik Bulgular}

Deney grubundaki üstün yetenekli çocuklarm sosyal duygusal beceri algisı tekrarlı ölçüm puanlar arasında anlamlı düzeyde fark varken, kontrol grubundaki üstün yetenekli çocuklarn sosyal duygusal beceri algısı tekrarlı ölçüm puanları arasında anlamlı düzeyde fark yoktur: Deney ve kontrol gruplarındaki üstün yetenekli çocukların Sosyal Duygusal Beceri Algısı tekrarlı ölçümleri arasında istatistiksel olarak anlamlı düzeyde farklılık olup olmadığı Wilcoxon İşaretli Sıralar Testi ile analiz edilmiş ve Tablo 10'da sunulmuştur.

Tablo 10. Deney ve Kontrol Gruplarının Sosyal Duygusal Beceri Algısı Ölçeği Ara Ölçümlerine İlişkin Wilcoxon İşaretli Stralar Testi Sonuçları

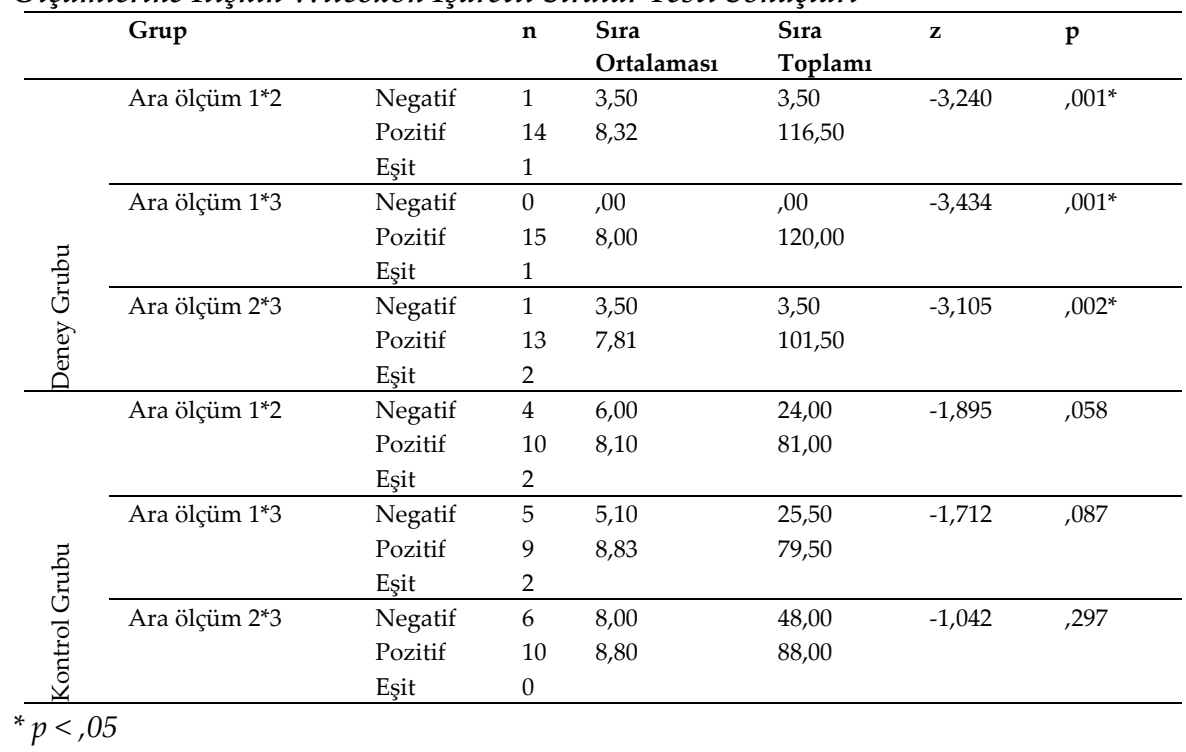

Tablo 10'a göre deney grubundaki üstün yetenekli öğrencilerin sosyal duygusal beceri algısı ara ölçümleri puanlarında anlamlı farklılık $(\mathrm{p}<, 05)$ 
olduğu, ancak kontrol grubundaki üstün yetenekli öğrencilerin sosyal duygusal beceri algısı ara ölçümleri arasında anlamlı farklılık $(\mathrm{p}>, 05)$ olmadığ1 görülmüştür. Bu durum deney grubundaki üstün yetenekli öğrencilerin sosyal duygusal becerilerinin program uygulama sürecinde zamanla artış gösterdiği ancak kontrol grubundaki üstün yetenekli öğrencilerin sosyal duygusal becerilerinin benzer düzeyde kaldığ yönünde yorumlanabilir.

Zaman içerisinde deney ve kontrol grubundaki öğrencilerin sosyal duygusal beceriler açısından nasıl bir gelişim gösterdikleri ve gruplar arasında bu gelişim açısından farklılık olup olmadığını belirlemek için tekrarlı ölçüm analizi modellerinden "Linear Mixed Effects Model" kullanılmıştır. Üstün yetenekli öğrencilerin sosyal duygusal beceri algısı puanlarının zamana göre değişimi öncelikle alt boyutlara ve sonrasında toplam puana göre analiz edilmiş ve aşağıda yer verilmiştir.

\section{Tablo 11.Benlik Saygısı Alt Boyutuna Yönelik Ara Ölçümler}

\begin{tabular}{llllll}
\hline Parametre & Kesim & se & df & t & p \\
\hline Sabit & 5,05 & 1,024 & 32,71 & 4,92 &, 00 \\
Deney-Kontrol (Uygulama) &, 029 &, 3719 & 29 &, 078 &, 93 \\
Öntest &, 630 &, 0804 & 29 & 7,84 &, 00 \\
Zaman &, 093 &, 1247 & 63 &, 751 &, 45 \\
\hline
\end{tabular}

Tablo 11'de üstün yetenekli öğrencilerin benlik sayg1sı puan ortalamalarının zamana göre değişimi sunulmuştur. Buna göre öntestten sonra katılımcıların benlik saygısı puanlarının ,630 arttığı görülmektedir. Programdan sonra üstün yetenekli öğrencilerin benlik saygısı puanlarının deney grubu lehine, 029 yüksek olduğu gözlemlenmiş ve bu fark istatistiksel olarak anlamlı bulunmamıştır (t:078; $\mathrm{p}>, 05)$. Bu durum göz önüne alındığında, benlik saygısını artıran becerilerde değişimi görmek için 2 haftalık zaman dilimlerinin yeterli olmadığı söylenebilir.

Tablo 12.İletişim Becerileri Alt Boyutuna Yönelik Ara Ölçümler

\begin{tabular}{llllll}
\hline Parametre & Kesim & se & df & t & p \\
\hline Sabit & 4,82 &, 8713 & 38,57 & 5,536 &, 00 \\
Deney-Kontrol (Uygulama) & 1,20 &, 3011 & 29 & 4,011 &, $00^{*}$ \\
Öntest &, 498 &, 0827 & 29 & 6,029 &, 00 \\
Zaman &,- 078 &, 1618 & 63,0 &,- 483 &, 63 \\
\hline
\end{tabular}

${ }^{*} p<, 05$ 
Tablo 12'de üstün yetenekli öğrencilerin iletişim becerileri puan ortalamalarının zamana göre değişimi sunulmuştur. Buna göre öntestten sonra katılımcıların iletişim becerileri puanlarının ,498 arttığ1 görülmektedir. Programdan sonra üstün yetenekli öğrencilerin iletişim becerileri puanlarının deney grubu lehine 1,20 yüksek olduğu gözlemlenmiş ve bu fark istatistiksel olarak anlamlı bulunmuştur (t:4.011; $\mathrm{p}<, 05)$. Bu durum iletişim becerileri puanlarındaki artışın tespit edilmesinde 2 haftalık zaman aralıklarının yeterli olduğu yönünde yorumlanabilir.

Tablo 13.Stresle Baş Etme Alt Boyutuna Yönelik Ara Ölçümler

\begin{tabular}{llllll}
\hline Parametre & Kesim & se & df & t & p \\
\hline Sabit & 3,67 & 1,067 & 33,91 & 3,44 &, 00 \\
Deney-Kontrol (Uygulama) &, 595 &, 3697 & 29 & 1,61 &, 11 \\
Öntest &, 753 &, 0782 & 29 & 9,63 &, 00 \\
Zaman &, 140 &, 1477 & 63,00 &, 952 &, 34 \\
\hline
\end{tabular}

Tablo 13'de üstün yetenekli öğrencilerin stresle baş etme puan ortalamalarının zamana göre değişimi sunulmuştur. Buna göre öntestten sonra katılımcların stresle baş etme puanlarının ,753 arttığ görülmektedir. Programdan sonra üstün yetenekli öğrencilerin stresle baş etme puanlarının deney grubu lehine ,595 yüksek olduğu gözlemlenmiş ve bu fark istatistiksel olarak anlamlı bulunmamıştır $(\mathrm{t}: 1,61 ; \mathrm{p}>, 05)$. Bu durum stresle baş etme becerilerindeki değişimi görmek için 2 haftalık zaman dilimlerinin yeterli olmadığı yönünde yorumlanabilir.

Tablo 14.Problem Çözme Becerisi Alt Boyutuna Yönelik Ara Ölçümler

\begin{tabular}{llllll}
\hline Parametre & Kesim & se & df & t & p \\
\hline Sabit & 4,12 &, 998 & 38,77 & 4,128 &, 00 \\
Deney-Kontrol (Uygulama) & 1,28 &, 336 & 29 & 3,809 &, $00^{*}$ \\
Öntest &, 713 &, 063 & 29 & 11,31 &, 00 \\
Zaman &,- 031 &, 187 & 63,00 &,- 167 &, 86 \\
\hline
\end{tabular}

${ }^{*} p<, 05$

Tablo 14'de üstün yetenekli öğrencilerin problem çözme becerisi puan ortalamalarının zamana göre değişimi sunulmuştur. Buna göre öntestten sonra katılımcların problem çözme puanlarının ,713 arttı̆̆ görülmektedir. Programdan sonra üstün yetenekli öğrencilerin problem 
çözme puanlarının deney grubu lehine 1,28 yüksek olduğu gözlemlenmiş ve bu fark istatistiksel olarak anlamlı bulunmuştur $(\mathrm{t}: 3,809 ; \mathrm{p}<$,05). Bu durum problem çözme becerileri puanlarındaki artışın tespit edilmesinde 2 haftalık zaman aralıklarının yeterli olduğu yönünde yorumlanabilir.

Tablo 15.Sosyal Duygusal Beceri Algısı Toplam Puanına Yönelik Ara Ölçümler

\begin{tabular}{llllll}
\hline Parametre & Kesim & se & df & t & p \\
\hline Sabit & 13,3 & 2,690 & 37,30 & 4,975 &, 00 \\
Deney-Kontrol (Uygulama) & 2,93 &, 7934 & 29,00 & 3,701 &, $00^{*}$ \\
Öntest &, 755 &, 0509 & 29 & 14,83 &, 00 \\
Zaman & 1,46 &, 4701 & 63 &, 000 & 1,0 \\
\hline
\end{tabular}

${ }^{*} p<, 05$

Tablo 15'de üstün yetenekli öğrencilerin sosyal duygusal beceri algısı toplam puan ortalamalarının zamana göre değişimi sunulmuştur. Buna göre öntestten sonra katılımcıların sosyal duygusal beceri algisı toplam puanlarının ,755 arttığ1 görülmektedir. Programdan sonra üstün yetenekli öğrencilerin sosyal duygusal beceri toplam puanlarının deney grubu lehine 2,93 yüksek olduğu gözlemlenmiş ve bu fark istatistiksel olarak anlamlı bulunmuştur (t:3,701; p <,05). Bu durum sosyal duygusal beceri puanlarındaki artışın tespit edilmesinde 2 haftalık zaman aralıklarının yeterli olduğu yönünde yorumlanabilir.

\section{Tartışma ve Sonuç}

Deney grubundaki üstün yetenekli öğrencilerin sosyal duygusal beceri algısı sontest puanlarının kontrol grubu sontest puanlarına göre anlamlı düzeyde yüksek olduğu tespit edilmiştir. Aynı zamanda deney grubunun sosyal duygusal beceri algısı toplam puanlarının öntest ve sontestleri arasında anlamlı farklılık olduğu sonucuna ulaşılmıştır. Bu durum, psiko-eğitim programına katılan üstün yetenekli öğrencilerin sosyal duygusal beceri algısı puanlarındaki artışı deneysel uygulamanın etkisinden kaynaklandığı şeklinde değerlendirilmiştir. Uygulanan psiko-eğitim programının sonundaki artışına etkisini görmek için izleme testi yapılmış ve izleme testi ile sontest puanları arasında anlamlı farklılık olmadığı görülmüştür. Buna göre psiko-eğitim 
programı ile elde edilen artışın kalıcı olduğu belirtilebilir. Diğer bir ifadeyle araştırma kapsamında geliştirilen psiko-eğitim programının üstün yetenekli çocukların sosyal duygusal beceri algılarında olumlu yönde ve kalıcı etkisi olduğu görülmüştür. Literatürde bazı araştırmalar bu bulguyu destekler niteliktedir (Bilgiç, 2000; Yukay, 2003).Baydan (2010) tarafından sosyal duygusal becerilere yönelik geliştirilen programın anlamlı farklılık oluşturduğu elde edilmiştir. Rosselet ve Stauffer (2013) tarafından üstün yetenekli çocuklara yönelik program geliştirilmiş ve uygulanan programın etkili olduğu görülmüştür. Köksal (2007) ise geliştirdiği program ile üstün yetenekli öğrencilerin duygusal zekâ puanlarının anlamlı şekilde farklılaştığını belirtmiştir. Bu araştırma sonuçlarına dikkat edilirse çeşitli programlar ile belli becerilerin belli kademelerdeki öğrencilere kazandırılması mümkündür. Ancak Köksal'ın (2007) da belirttiği gibi üstün yetenekli çocuklar bu çalışmalarda çok az yer almakta ve ihmal edilmektedir. Üstün yeteneklilerin sosyal duygusal gelişimlerine ilişkin daha önceki çalışmalarda desteğe ihtiyaç duydukları da bilinmektedir (Cigman, 2004; Moon, Kelly ve Feldhusen, 1997; Özbay ve Palancı, 2011). Bu bağlamda, üstün yetenekli çocuklara yönelik psiko-eğitim programının hazırlanması gerektiği fark edilmiştir. Buna dayalı olarak bu program geliştirilmiş ve uygulanmıştır. Üstün yetenekli öğrencilerin özellikleri göz önünde bulundurularak geliştirilen psiko-eğitim programlarının bu çocuklar üzerinde etkili olduğu görülmüştür. Geliştirilen programın etkili olması iletişim sürecindeki olası problem durumlarına ve empatiye yer verilmesi, yaşantısal yönünün olması ile açıklanabilmektedir. Kazandırılması hedeflenen becerilerin grup sürecinde uygulanması da buna katkı sağlamış olabilir. Eğitim programlarının sistematik şekilde sunulması ve üstün yetenekli öğrencilerin özellikleri dikkate alınarak program hazırlanması katılımcıların sosyal duygusal öğrenmelerine katkıda bulunduğu düşünülmektedir (Heller, 2004; Neihart, 2007).

İletişim becerileri ve problem çözme becerilerine yönelik yapılan analizler sonucunda deney grubunda bulunan üstün yetenekli öğrencilerin iletişim becerileri ve problem çözme becerilerine ilişkin öntest ve sontest puanlarında anlamlı farklılık olduğu görülmüştür. Tekrarlı ölçümlerle bu fark üzerinde uygulanan programın etkili olduğu vurgulanmıştır. Elde edilen farklılık üzerinde zamanın anlamlı etkisi 
olmadığı görülmüştür. Literatürdeki bazı araştırmalar mevcut çalışmada elde edilen bu bulguyu destekler niteliktedir(Korkut, 2005).Bildiren ve Kargın'ın (2019) çalışmasında, üstün yetenekli öğrencilere yönelik geliştirilen programın deney grubundaki öğrencilerin problem çözme becerilerini artırdığı görülmüştür. Totan (2011) ve Köksal (2007) tarafından yapılan çalışmalarda da benzer sonuçlar elde edilmiştir. Bazı araştırmalarda ise uygulanan programların katılımcıların iletişim becerilerinde anlamlı farklılık oluşturmadı̆̆ tespit edilmiştir (Siyez ve Tan-Tuna, 2014; Totan, 2011). Mevcut araştırmada, uygulanan psikoeğitim programı ile üstün yetenekli öğrencilerin iletişim becerilerinde ve problem çözme becerilerinde artış olduğu bulgulanmıştır. İletişim konusu üzerinde yoğunlaşılması, deney grubundaki öğrencilerin iletişimin önemini fark etmesi, iletişim sürecinin öğrenilebilir olması ve oturumlarda uygulamaya yer verilmesi bu duruma katkı sağlamış olabilir. Üstün yetenekli öğrencilerin zihinsel özellikleri ile bu durum açıklanabilir. Katılımcıların oturumlara düzenli katılması ve ev ödevlerini gerçekleştirmeleri de programın etkililiğini güçlendirmiş olabilir. Aynı zamanda uygulanan programda üstün yetenekli öğrencilerin olası yaşayabilecekleri problemlere yer verilmiştir. Böylece olası problemlerin çözümleri oturumlarda tartışılmıştır. Ayrıca diğer grup üyelerinin de benzer problem yaşadıklarını görmeleri ve çözüm önerilerini kendileri gibi kişilerden de duymuş olmaları problem çözme becerileri açısından uygulanan programı güçlü kılmıştır.

Benlik saygısını artıran beceriler ve stresle baş etme becerilerine yönelik yapılan analizler sonucunda deney grubunda bulunan üstün yetenekli öğrencilerin benlik saygılarına ve stresle baş etme becerilerine ilişkin öntest ve sontest puanlarında anlamlı farklılık olduğu görülmüştür. Bu bulgu literatürdeki bazı araştırmaların sonuçları ile paralellik göstermektedir (Bilgiç, 2000; Farnoodian, 2016; Radd ve Harsh, 1996).Saçkes'in (2004) çalışmasında uygulanan programın katılımcıların benlik saygılarında anlamlı farklılık oluşturduğu görülmüştür. Demir (2014) tarafından yapılan çalışmanın sonucunda, katılımcıların stres puanlarında azalma olduğu tespit edilmiştir. Akkuş- Çutuk (2017) ve Altunkol (2017) tarafından yapılan çalışmalarda, deney grubunun stres düzeylerinin azaldığı ve kontrol grubuna göre anlamlı farklılık olduğu tespit edilmiştir. Yapılan bazı araştırmalarda ise uygulanan 
programların benlik saygısını artırmada ve stres düzeyini azaltmada anlamlı farklılık oluşturmadığı görülmüştür (Aydın ve İmamoğlu, 2001; Sert, 2003). Mevcut araştırma kapsamında psiko-eğitim programı ile üstün yetenekli çocukların benlik saygısını artıran beceriler ve stresle baş etme becerilerinde artış sağlandığı görülmüştür. Hazırlanan programda bu değişkenlere ilişkin yeterli sayıda etkinliğe yer verilmesi, programda öğrencilerin kendilerini tanımasına ilişkin çalışmaların olması, üstün yetenekli öğrencilerin özelliklerinin dikkate alınarak program hazırlanması, üstün yetenekli öğrencilerin bilişsel kapasiteleri ve katılımcıların ilkokul döneminde olması ile elde edilen artış açıklanabilmektedir. Bu bağlamda bu çalışmanın koruyucu ve önleyici yönünün olduğu da söylenebilir.

Benlik saygısını artıran becerilerin ve stresle baş etme becerilerinin zamana göre değişimini incelemek amacıyla tekrarlı ölçümler yapılmış ve anlamlı sonuçlar elde edilmemiştir. Bu bağlamda hem benlik saygısını artıran beceriler hem de stresle baş etme becerilerine ilişkin yapılan 8 hafta zaman aralığı olan öntest ve sontest ölçümlerinde anlamlı farklılık olmasına rağmen 2 haftalık ölçümlerde bu farklılık tespit edilmemiştir. Buradan hareketle 2 haftalık süreçlerin değişimi gözlemlemek için yeterli olmadığı ve daha uzun zaman aralıklarında ölçümlerin yapılması gerekliliği belirtilebilir. Benzer şekilde Clark ve Dixon (1997) tarafından yapılan çalışmada da 3 haftalık program uygulanmıştır. Ancak 3 hafta sonunda benlik saygısına yönelik anlamlı farklılık elde edilememiştir. Bu durum benlik saygısı ve stresle baş etme becerileri kavramlarının özellikleri ile açıklanmaktadır (Kaplan, 1990). Bu kapsamda benlik ve stres gibi özelliklerin değişimi için daha uzun zamanın gerektiği belirtilebilir.

Yalnızlık düzeyine ilişkin bulgular incelendiğinde, deney ve kontrol grubunun yalnızlık düzeyi sontest puanlarında anlamlı farklılık elde edilememiştir. Aynı zamanda deney grubundaki üstün yetenekli öğrencilerin öntest ve sontest puanları arasında anlamlı farklılık bulunmamıştır. Bu bulguya göre program sonunda deney ve kontrol grubundaki öğrencilerin yalnızlık düzeylerinin benzer olduğu belirtilebilir. Bu bağlamda yalnızlık düzeyi üzerinde 8 haftalık bir programın etkili olmadığı ortaya konulmuştur. $\mathrm{Bu}$ durum, üstün yetenekli öğrencilerin farkındalıkları ve duyarlılıkları gibi özellikleri ile 
açıklanabilir. Olayları algılama biçimlerinin yalnızlık düzeylerini artırdığı söylenebilir. "Yalnızlık, bazı kişiler için istendik şekilde tercih edilen bir durum mu?" sorusu da hala araştırmalara konu olmaktadır. Bazı çalışmalarda ise bireylerin kişisel faktörleri ile ilişkili yalnızlık durumunda farklılaşma olmayacağı belirtilmektedir (Özbay ve Palancı, 2011).

Mevcut araştırmada elde edilen sonucun aksine yalnızlığı azaltmaya yönelik bazı çalışmalar yapılmış ve bu çalışmalarda anlamlı farklılıklar elde edilmiştir. Bu araştırmalardan biri Uysaler (2015) tarafından gerçekleştirilmiştir. Üstün yetenekli öğrencilere yönelik yapılan bu çalışmada uygulanan programın katılımcıların sontest yalnızlık puanlarında anlamlı farklılık sağladığı görülmüştür. Duy (2003) ve Bilgiç (2000) tarafından yapılan çalışmalarda bu sonuçla benzerlik göstermektedir. Tatlığlu (2013) ise çevrimiçi terapinin yalnızlı̆̆1 azaltmada etkili olduğunu ortaya koymuştur. Bu çalışmalarda beklenilen farklılığın oluşması psiko-eğitimin beceri kazandırmaya dönük etkinlikler içermesi, yaşantıya dayalı olması, eğlenceli oyunlara, hikâyelere yer verilmesi ve iyileştirmeye yönelik olması ile açıklanmıştır.

Mevcut çalışmada yalnızlık düzeyinin kalıcılığını görmek amacıyla izleme testi yapılmıştır. Yapılan analiz sonucunda deney grubunun yalnızlık düzeyi sontest ve izleme testi arasında anlamlı farklılık tespit edilmiştir. Bu bulgu, psiko-eğitim programının yalnızlık düzeyi üzerinde daha uzun süre sonra etkisini gösterdiği yönünde yorumlanmıştır. Bu kapsamda, sosyal duygusal öğrenmelerin yaşama yansıması ve yalnızlık düzeylerinde etki yaratması için 8 haftadan daha fazla süreye gerek olduğu belirtilebilir. Bu durum, yalnızlık kavramının özelliği ve değişime daha dayanıklı bir yönünün olması ile açıklanabilir. Buradan hareketle yalnızlık kavramına yönelik çalışmaların daha uzun süreli planlanması gerektiği düşünülmektedir. Duy (2003) ve Bilgiç (2000) tarafından yapılan araştırmalarda bu görüşü destekler sonuçlar elde edilmiştir.

Arkadaşlık niteliklerine ilişkin bulgular incelendiğinde, deney ve kontrol grubunun arkadaşlık niteliği sontest puanlarında anlamlı farklılık elde edilmiştir. Aynı zamanda deney grubundaki üstün yetenekli öğrencilerin öntest ve sontest puanları arasında anlamlı farklılık bulunmuştur. Bu bağlamda, psiko-eğitim programının üstün 
yetenekli çocukların arkadaşlık niteliklerinde olumlu etkisi olduğu söylenebilir. Bu etkinin devam edip etmediğini görmek için izleme testi yapılmış ve deney grubunun arkadaşlık niteliği izleme testi ve sontest puanları arasında anlamlı farklılık bulunmadığı görülmüştür. Bu durum arkadaşlık niteliğine ilişkin artışın kalıcı olduğu yönünde yorumlanmıştır. Bu bulguyu destekleyen araştırmalar literatürde yer almaktadır. Uysaler (2015) tarafından üstün yetenekli öğrencilerin arkadaşlık ilişkilerini geliştirmek amacıyla program uygulanmış ve uygulamanın etkili olduğu görülmüştür. Çetin, Bilbay ve Kaymak (2002) ve Özaydın (2006) tarafından yapılan çalışmalarda da benzer sonuçlar elde edilmiştir. Literatürde karşıt sonuç elde eden çalışmalarda yer almaktadır (Demir ve Kaya, 2008).

Mevcut çalışmada, üstün yetenekli öğrencilerin arkadaşlık niteliklerinin olumlu gelişmesinde psiko-eğitim programının etkili olduğu görülmüştür. Bu duruma, programda katılımcıların arkadaşlık ilişkilerinde yaşayabilecekleri olası sorunlara yer verilmesi, rol oynama gibi etkinliklerin yapılması, oturum süresi ve oturuma düzenli katılma gibi etmenler katkı sağlamış olabilir. İletişim becerilerinin güçlenmesinin de arkadaşlık ilişkilerini daha iyi duruma getirdiği söylenebilir.

Özetle, genel olarak psiko-eğitim programının etkili olmasına; program hazırlanmadan önce literatürün detaylı taranması, sosyal duygusal gelişime ilişkin yurtiçi ve yurtdışı çalışmalarının incelenmesi, üstün yetenekli öğrencilerin sosyal duygusal özelliklerinin uzun süreli gözlemlenmesi, anne-babalarla görüşme yapılarak gerekli bilgilerin alınması, alan uzmanlarının görüşlerinin alınması ve dönütlerle gerekli güncellemelerin yapılması katkı sağlamış olabilir. Aynı zamanda üstün yetenekli öğrencilerin özelliklerine dikkat edilerek programda tekrara düşülmemesine, etkinliklerde harekete daha fazla yer verilmesine ve yaratıcı düşünmeyi gerektiren çalışmaların planlanmasına dikkat edilmiştir. Oturumların süresinin çocuklara uygun şekilde belirlenmesine, etkileşime daha çok yer verilmesine, yaşantısal yönü olan bir program hazırlanmasına özen gösterilmiştir. Programdaki ifadeler, ebeveyn ve öğretmenlerle yapılan görüşmeler neticesinde belirlenmiş ve üstün yetenekli öğrencilerin ilgi alanlarını oluşturan nesli tükenen hayvanlara, çizimlere ve uzay gibi konulara yer verilmiştir. Tartışma soruları ile katılımcıların düşüncelerine ifade etme fırsatı 
tanınmış ve grup sürecinde aktif olmalarına fırsat tanınmıştır. Her oturum sonuna değerlendirme konulmuş böylece eksiklikler süreç içerisinde de görülmeye çalışılmıştır. Sosyal duygusal öğrenmelerin ev ödevleri ile grup sonrası pekiştirilmesine de özen gösterilmiştir. Çocuklara yönelik yapılan grup etkinliklerinde az sayıda öğrenci olmasının etkililiği artırdığı görüşünden yola çıarak grup sayısı 8 öğrenciyle sinırlı tutulmuştur. Tekrarlı ölçümlerle de elde edilen değişimler üzerinde zamanın etkisi test edilmiştir.

$\mathrm{Bu}$ araştırmanın bazı eksiklikleri de bulunmaktadır. Anne baba tutumları, öğretmen tutumları gibi sosyal duygusal gelişim ile ilişkili olabilecek değişkenler bu araştırmada ele alınmamıştır. Bu durum mevcut araştırmanın sınırlılığı olabilir. Sosyal duygusal gelişim, oldukça uzun soluklu çalışmaları gerektirmektedir. Dünyada uzun süreli çalışma örnekleri bulunmaktadır. Ancak bu çalışmada sürenin kısıtlı olması nedeniyle zaman sinırlandırılmış ve 8 oturumluk bir program planlanmıştır. Oturum sayısı da bu araştırmanın diğer bir sınırlılığını oluşturduğu söylenebilir.

Çalışmada elde edilen sonuçlar aşağıda verilmiştir.

1. Uygulanan psiko-eğitim programının üstün yetenekli çocukların sosyal duygusal beceri algıları ve arkadaşlık nitelikleri üzerinde olumlu yönde etkili olduğu görülmüştür. Ancak yalnızlık düzeyine ilişkin farklılık izleme testinde tespit edilmiştir.

2. Program uygulama sonrasinda deney grubunun sosyal duygusal becerilerinde ve arkadaşlık niteliklerinde kontrol grubuna göre artış olmuştur. Ancak bu durum yalnızlık düzeylerinde gözlemlenmemiştir.

3. Uygulanan program sonunda deney grubundaki üstün yetenekli öğrencilerin sosyal duygusal becerileri ve arkadaşlık niteliklerinin önteste göre artış gösterdiği sonucuna ulaşılmıştır. Ancak yalnızlık düzeyleri sontest ve öntest puanları arasında farklılık olmadığı görülmüştür.

4. Araştırmada, izleme ölçümleri yapılmış ve uygulanan programın etkisinin sosyal duygusal beceri algıları ve arkadaşlık nitelikleri üzerinde kalıcı olduğu görülmüştür. Yalnızlık düzeyinde ise izleme testi puanı son test puanına göre anlamlı düzeyde farklılaşmıştır. 
5. Deney grubunun sosyal duygusal beceri alt boyutlarında program sonunda anlamlı düzeyde artış tespit edilmiştir.

6. Araştırmanın tekrarlı ölçümlerinde, deney grubundaki çocukların sosyal duygusal beceri algıları, problem çözme becerileri ve iletişim becerileri alt boyutları puanlarında 2 haftalık periyotlarda programın etkisiyle artış olduğu görülmüştür. Benlik saygısını artıran beceriler ve stresle baş etme becerilerinde 2 haftalık zaman aralıklarında programın etkililiği sınanmamıştır.

Tüm bu sonuçlardan hareketle; yalnızlık düzeylerine yönelik yapılacak çalışmaların daha uzun süreli olması gerektiği düşünülmektedir. Sosyal duygusal beceri algısı, yalnızlık ve arkadaşlık niteliğine yönelik ayrı ayrı programlar hazırlanması önerilebilir. Bu durum tüm özelliklerin daha derinlemesine çalışılmasına ve bu özelliklerin üstün yetenekli çocuğa kazandırılmasına fırsat tanıyacaktır. Araştırmada, deney program bittikten 5 hafta sonra izleme ölçümleri yapılmıştır. Kalıcılığının devam edip etmediğini görmek için 6 ay-12 ay gibi süreçlerde ölçümler yapılabilir. Bu araştırma ilkokuldaki öğrencilere yönelik hazırlanmıştır. Ergenlik gibi farklı gelişim dönemlerindeki üstün yetenekli öğrencilerin özellikleri göz önüne alınarak hazırlanan programların etkililiği incelenebilir. Günümüzde gelişmiş ülkelerin eğitim programları incelendiğinde sosyal duygusal gelişime yönelik çalışmalar örgün eğitim-öğretim programlarıyla birlikte sunulmaktadır. $\mathrm{Bu}$ bağlamda, zamana yayılarak uzun süreli devam eden programlar hazırlanarak uygulanması önerilebilir. Mevcut çalışmada, sosyal duygusal gelişimin bazı yönleri ele alınmıştır. Bu araştırma kapsamına alınmayan sosyal duygusal gelişimin diğer boyutlarına ilişkin çalışmaların planlanması üstün yetenekli çocukları daha iyi anlamamıza katkı sağlayacaktır. Üstün yetenekli çocuk ve ergenler Türkiye'de BİLSEM'lerde desteklenmektedir. BİLSEM'ler de bu program uygulanırken gruba alınacak öğrencilerin özelliklerine göre programda yeniden yapılandırma (süre, oturum sayısı, rol oynama etkinlikleri vd.) yapılabilir. Etkinlikler uygulanırken tartışma sorularının azaltılmasının da oturumları daha etkin kılacağı düşünülmektedir. Psikolojik danışma ve rehberlik hizmetlerinin kanıta dayalı şekilde yürütülmesi açısından, bilimsel yönü ağır basan programlara yer verilmesi önerilebilir. 


\title{
EXTENDED ABSTRACT
}

\section{TheEffect of Psycho-Education Program Developed for the Social Emotional Development of Gifted Children}

\author{
* \\ Seda Sevgili Koçak- Adnan Kan \\ Söke Science and Art Center-Gazi University
}

Problem: The future of countries is closely related to developing their talents. It is thought that by contributing to the development of gifted individuals, their contribution to society and humanity will be more. For this reason, studies on gifted individuals have increased nowadays. Early identification of gifted children and the development of their abilities have gained importance in our age. For the Science and Art Center, student identification starts in the first grade of primary school, enabling the early detection of gifted children. This makes the studies covering the primary school periods of gifted children important. Despite the increase in research on the gifted, experimental studies are not sufficient. It is hoped that this research will contribute to filling this gap. At the same time, it is thought that it will support the field of guidance and psychological counseling in terms of evidence-based practices. The objective of this study is to analyse the effects of the psycho-education program developed for the social-emotional development of gifted students on social emotional skills, loneliness and friednship qualities.

Method: The research was carried out with the gifted students at the 3rd and 4th grade levels, attending the Science and Art Centre in Aydin in the 2018-2019 academic year. The study group consisted of 32 gifted students; 2 experimental (16 gifted students) and 2 control (16 gifted students) groups. The data of the research were; "Social-Emotional Ability Perception Scale", "Friendship Quality Scale" and "Loneliness Scale for Children" were collected by applying. Within the scope of the study, 8 sessions of the psycho-education program were applied to the experimental groups and no study was conducted on the control groups. The research design is a quasi-experimental model with experimental 
and control groups (pre-test, intermediate measurement 1 , intermediate measurement 2 , and intermediate measurement 3, post-test, follow-up test-1). The dependent variables of the study consisted of socialemotional skill perception, loneliness level and friendship quality and the independent variable was the psycho-education program prepared for the social-emotional development of gifted students. The measurement instruments used in the research were pre-tested 1 week before the implementation of the program; intermediate measurements at two-week intervals; post-test after completion of the program; followup test was applied 5 weeks after the last test in order to determine the permanence of the program's effect. Whit "Mann Whitney U", "Wilcoxon Signed Sequences Test" and "Linear Mixed Effects Model" were used for the data analysis and the results were analysed in SPSS 21 program.

Findings: The findings of the study showed that the psycho-education program applied increased the students' perceptions of social-emotional skills and friendship qualities, but did not provide any differentiation in loneliness level. It was observed that there was a significant difference between the post-test scores of the gifted students in the experimental group and their social-emotional skills perceptions and friendship quality post-test scores. In the study, follow-up measurements were made and it was observed that the effect of the program applied was permanent on perceptions of social emotional skills and friendship qualities. At the loneliness level, the follow-up test score differed significantly from the post-test score. At the end of the program, a significant increase was detected in the social emotional skills subdimensions of the experimental group. In the repeated measurements of the study, it was observed that the social emotional skill perceptions, problem solving skills and communication skills sub-dimensions scores of the children in the experimental group increased in 2-week periods with the effect of the program. The effectiveness of the program has not been tested in 2-week time intervals in skills that increase self-esteem and skills in coping with stress.

Results: In line with these results, it can be said that the psychoeducation program developed for the social-emotional development of gifted students is effective. All the findings obtained from the research 
were discussed with the relevant studies in the literature and suggestions were presented. These recommendations are: This research was prepared for primary school students. The effectiveness of the programs prepared by considering the characteristics of gifted students in different developmental stages such as adolescence can be examined. Today, when the education programs of developed countries are examined, studies on social and emotional development are presented together with formal education programs. In this context, it can be recommended to prepare and implement long-term programs spread over time. In the present study, some aspects of social emotional development are discussed. Planning studies on other dimensions of social-emotional development, which are not included in this research, will contribute to a better understanding of gifted children.

\section{Kaynakça / References}

Akkuş-Çutuk, Z. (2017). Duygusal dışavurum amaçlı psiko-eğitim programının ergenlerin depresyon, anksiyete ve stres düzeyine etkisi. Yayınlanmamış doktora tezi. Sakarya Üniversitesi, Eğitim Bilimleri Enstitüsü, Eğitimde Psikolojik Hizmetler Bilim dalı, Sakarya.

Altunkol, F. (2017). Bilişsel esneklik eğitim programının lise öğrencilerinin bilişsel esneklik ile algılanan stres düzeylerine ve stresle başa çıma tarzlarma etkisi. Yayınlanmamış doktora tezi. Çukurova Üniversitesi, Sosyal Bilimler Enstitüsü, Eğitim Bilimleri Anabilim dalı, Adana.

Asher, S. R. ve Wheeler, V. A. (1985). Children's loneliness: A comparison of rejected and neglected peer status. Journal of Consulting and Clinical Psychology, 53(4), 500-505. https://doi.org/10.1037/0022-006X.53.4.500.

Aydın, B. ve İmamoğlu, S. (2001). Stresle başa çıkma becerisi geliştirmeye yönelik grup çalışması. M.Ü. Atatürk Eğitim Fakültesi Eğitim Bilimleri Dergisi, 14, 41-52.

Aydın, O. ve Konyalığlu, P. (2011). 18-21 Yaş grubu bireylerin genel zeka düzeyleri ile psikolojik semptom düzeyleri arasındaki ilişki. Türk Üstün Zekâ ve Eğitim Dergisi, 1(1), 77-103.

Bainbridge, C. (2011). SocialandEmotionalProblemsAffectingGifted Children.http://giftedkids.about.com/od/socialemotionalissues/a/gtproblems. htmadresinden erişildi. 
Baydan, Y. (2010). Sosyal-Duygusal Beceri Algısı Ölçeği'nin geliştirilmesi ve sosyal-duygusal beceri programının etkililiği. Yayınlanmamış doktora tezi, Sosyal Bilimler Enstitüsü, Psikolojik Danışmanlık ve Rehberlik Bilim dalı, Hacettepe Üniversitesi, Ankara.

Bildiren, A. (2018). Özel eğitimin üstün yetenekli çocuklar üzerinde benlik algısına etkisi. Kastamonu Eğitim Dergisi, 26(5), 1489-1498. https://doi.org/10.24106/kefdergi.397345

Bildiren, A. ve Kargın, T. (2019). Proje temelli yaklaşıma dayalı erken müdahale programının üstün yetenekli çocukların problem çözme becerisine etkisi. Eğitim ve Bilim, 44(198), 343-360. DOI: 10.15390/EB.2019.7360

Bilgiç, N. (2000). Arkadaşlık becerisi eğitiminin ilköğretim II. kademe öğrencilerinin yalnızlık düzeylerine etkisi. Yayınlanmamış yüksek lisans tezi. Gazi Üniversitesi, Eğitim Bilimleri Enstitüsü, Eğitim Bilimleri Anabilim dalı, Ankara.

Bingham, A. (2004). Çocuklarda problem çözme yeteneklerinin geliştirilmesi. (F. Oguzkan, Çev.). İstanbul: Milli Eğitim Bakanlığı Yayınları.

Brown, N. W. (2013). Psikolojik danışmanlar için psiko-eğitsel gruplar hazırlama ve uygulama rehberi. (V. Yorğun, çev.). Ankara: Anı.

Buluş, M. (1997). Üniversite öğrencilerinde yalnızlık. Pamukkale Üniversitesi Ĕ̆itim Fakültesi Dergisi, 3, 82-90.

Cigman, R. (2004). Situated self-esteem. Journal of Philosophy of Education, 38(1), 91-105.

Clark, J. J. ve Dixon, D. N. (1997). The impact of social skills training on the self-concepts of gifted high school students. Journal of Advanced Academics, 8(4), 179-188.

Cohen, J. (1988). Statistical power analysis for the behavioral sciences (2nd ed.). Hillsdale, NJ: Erlbaum.

Cüceloğlu, D. (1994). İnsan ve davranışı. Psikolojinin temel kavramları. İstanbul: Remzi.

Çetin, F.,Bilbay, A.A. ve Kaymak, A.D. (2002). Araştırmadan uygulamaya çocuklarda sosyal beceriler grup eğitimi. İstanbul: Epsilon Yayınları.

Demir, S. ve Kaya, A. (2008). Grup rehberliği programının ergenlerin sosyal kabul düzeyleri ve sosyometrik statülerine etkisi. Elementary Education Online, 7(1), 127-140.

Demir, V. (2014). Bilinçli farkındalık temeli hazırlanan eğitim programının bireylerin depresyon ve stres düzeyleri üzerine etkisi. Yayınlanmamış 
yüksek lisans tezi. İstanbul Arel Üniversitesi, Sosyal Bilimler Enstitüsü, Psikoloji Anabilim dalı, İstanbul.

Dixon, F.A., Lapsley, D.K. ve Hanchon, T. A. (2004). An empirical typology of perfectionism in Gifted adolescents. Gifted Child Qoarterly, 48(2), 95106.

Duy, B. (2003). Bilişsel davranış̧̧ı yaklaşıma dayalı grupla psikolojik danışmanın yalnızlı ve fonksiyonel olmayan tutumlar üzerine etkisi. Yayınlanmamış doktora tezi. Ankara Üniversitesi, Eğitim Bilimleri Enstitüsü, Rehberlik ve Psikolojik Danışmanlık Bilim dalı, Ankara.

Elias, M. J. (2003). Academic and social-emotional learning, educational practices.Geneva: International Academy of Education and the International Bureau of Education (UNESCO). https://unesdoc.unesco.org/ark:/48223/pf0000129414 sayfasından erişildi.

Eraslan-Çapan, B. (2006). Çocukların kendilik değerinin geliştirmede kendilik değerini geliştirme programı ve sosyal duygusal eğitim programının etkililiği. Yayınlanmamış doktora tezi. Hacettepe Üniversitesi, Sosyal Bilimler Enstitüsü, Psikolojik Danışmanlık ve Rehberlik Bilim dalı, Ankara.

Farnoodian, P. (2016). The effectiveness of group reality therapy on mental health and self-esteem of students. International Journal of Medical ResearchEHealth Sciences, 5, 18-24.

Gagne, F. (2005). From noncompetence to exceptional talent: Exploring the range of academic achievement within and between grade levels. Gifted Child Quarterly, 49, 139-153.

Güçray, S. S., Çekici, F. ve Çolakkadığlu, O. (2009). Psiko-eğitim gruplarının yapılandırılması ve genel ilkeleri. Mersin Üniversitesi Eğitim Fakültesi Dergisi,5(1), 134-153.

Heller, K. A. (2004). Identification of giftedandtalentedstudents. PsychologyScience, 46(3), $302-323$.

Kaiser, C. F. ve Berndt, D. J. (1985). Predictors of loneliness in the Gifted adolescent. Gifted Child Quarterly, 29(2), 7477. https://doi.org/10.1177/001698628502900206

Kaplan, L. S. (1990). Helping gifted students with stres management. https://files.eric.ed.gov/fulltext/ED321493.pdf $\quad 01.02 .2020$ tarihinde adresinden erişildi.

Karasar, N. (2005). Bilimsel araştırma yöntemi: Kavramlar- ilkeler- teknikler. Ankara: Nobel. 
Kaya, A. (2005). Çocuklar için yalnızlık ölçeğinin Türkçe formunun geçerlik ve güvenirlik çalışması. EurasianJournal of Educational Research, 19, 220237.

Kılıç, M. ve Koç, M. (2003). Üniversite öğrencilerinin problem çözme düzeylerinin mesleki eğtiim programları açısından karşılaştırılması. Niğde Üniversitesi Ĕ̆itim Fakültesi Dergisi, 2,1-16.

Korkut, F. (2005). Yetişkinlere yönelik iletişim becerileri eğitimi. Hacettepe Üniversitesi Ĕ̆itim Fakültesi Dergisi, 28, 143-149.

Köksal, A. (2007). Üstün zekâlı çocuklarda duygusal zekâyı geliştirmeye dönük program geliştirme çalışması. Yayınlanmamış doktora tezi. İstanbul Üniversitesi, Sosyal Bilimler Enstitüsü, Eğitimde Psikolojik Hizmetler Anabilim dalı, İstanbul.

Landau, S. ve Everitt, B. S. (2004). A handbook of statistical analyses using SPSS.London: Chapman\&Hall/CRC.

Milli Eğitim Bakanlığı (MEB) (2019). BİLSEM Yönergesi. http://orgm.meb.gov.tr 01.02.2020 tarihinde adresinden erişilmiştir.

Moon, S. M.,Kelly, K. R. ve Feldhusen, J. (1997). Specialized counseling services for gifted youth and theirfamilies: A needs assessment. Gifted Child Quarterly, 41, 16-25.

Neihart, M. (2007). The socio affective impact of acceleration and ability grouping: Recommendations for best practice. Gifted Child Quarterly, 51(4), 330-341.

Özaydın, L. (2006). Arkadaşlık becerilerini geliştirme programının özel gereksinimi olan ve olmayan okul öncesi çocuklarının sosyal etkileşimlerine etkisi. Yayınlanmamış doktora tezi. Ankara Üniversitesi, Eğitim Bilimleri Enstitüsü, Özel Eğitim Anabilim dalı, Ankara.

Özbay, Y. ve Palancı, M. (2011) Üstün yetenekli çocuk ve ergenlerin psikososyal özellikleri. Sakarya Üniversitesi Eğitim Fakültesi Dergisi, 22, $89-108$.

Öztürk, N. (2016). Arkadaşlık becerisi psiko-eğitiminin 9-12 yaş arası öğrencilerin arkadaşlık niteliğine etkisi. Yayınlanmamış doktora tezi. İnönü Üniversitesi, Eğitim Bilimleri Enstitüsü, Psikolojik Danışmanlık ve Rehberlik Bilim dalı, Malatya.

Parker, J. G. ve Asher, S. R (1993). Friendshipandfriendshipquality in middle childhood: Links with peer groupacceptanceandfeelings of loneliness and social dissatisfaction. Developmental Psychology, 29(4), 611-621. DOI: $10.1037 / 0012-1649.29 .4 .611$ 
Payton, J. W.,Wardiaw, D. M., Graczyk, P. A., Bloodworth, M. R., Tompsett, C. J., ve Weissberg, R. P. (2000). Social and emotional learning: A framework for promoting mental healthandreducing risk behavior in children and youth. Journal of School Health, 70, 179-185.

Peterson, J.,Duncan, N. ve Canady, K. (2009). A longitudinal study of negative life events, stres and school experiences of gifted youth. Gifted Child Quarterly, 53(1), 34-49.

Radd, T. R. ve Harsh, A. F. (1996). Creating A Healthy Classroom Climate While Facilitating Behavior Change: A Self-ConceptApproach. Elementary School Guidance and Counseling, 31(2), 153-159.

Renzulli, J. S. ( 1999). What is thingcalledgiftedness, and how do wedevelop it? atwenty- fiveyearperspective. JournalfortheEducation of Gifted, 23(1) 3-54.

Rosselet, J. G. ve Stauffer, S. D. (2013). Using role-playing games with gifted children and adolescents: A psychosocial intervention model. International Journal of Play Therapy, 22(4), 173-192.

Shapiro, L. E. (2010). Yüksek EQ'lu bir çocuk yetiştirmek. (Ü. Kartal, çev.). İstanbul: Varlık Yayınları.

Siyez, D. M. ve Tan-Tuna, D. (2014). Lise öğrencilerinin öfke kontrolü ve iletişim becerilerinde çözüm odaklı psiko-eğitim programının etkisi. Türk Psikolojik Danışma ve Rehberlik Dergisi, 5(41), 11-22.

Smutny, J. F. (2001). Standupfor your giftedchild.Canada: FreeSpirit Publishing.

Stuart, T. ve Beste, A. (2008). Farklı olduğumu biliyordum: Üstün yeteneklileri anlayabilmek. Ankara: Kök.

Tatlığlu, K. (2013). Th eeffect of cognitive behavioral oriented psycho education program on dealing with loneliness: An online psychological counseling approach. Education Aroundthe World, 134(1), 101-109.

Totan, T. (2011). Problem çözme becerileri eğitim programının ilköğretim 6. sinıf öğrencilerinin sosyal duygusal öğrenme becerileri üzerine etkisi. Yayınlanmamış doktora tezi. Dokuz Eylül Üniversitesi, Eğitim Bilimleri Enstitüsü, Rehberlik ve Psikolojik Danışmanlık Bilim dalı, İzmir.

Uysaler, H. (2015). Arkadaşlık becerilerini geliştirme programının üstün zekâlı öğrencilerin arkadaşlık ilişkilerine etkisi. Yayınlanmamış doktora tezi. İstanbul Üniversitesi, Eğitim Bilimleri Enstitüsü, Üstün Zekalılar Eğitimi Bilim dalı, İstanbul. 
Yukay, M. (2003). Ilköğretim 3.sımı öğrencilerine yönelik sosyal beceri programının değerlendirilmesi. Yayınlanmamış doktora tezi. Marmara Üniversitesi, Eğitim Bilimleri Enstitüsü, Rehberlik ve Psikolojik Danışmanlık Bilim dalı, İstanbul.

\section{Ek. Psiko-eğitim Programı Oturum Özetleri}

1. Oturumda öğrencilere grup süreci ve grubun amacı hakkında bilgi verilmiştir. Tanışma etkinliği yapılmış ve grup üyelerinin birbirlerini tanıması sağlanmıştır. Tanışma etkinliği sonrasında tartışma soruları sorularak grup üyelerinin görüşleri alınmıştır. "En'lerim" formu grup üyelerine dağıtılmış ve doldurmaları için zaman verilmiştir. Etkinlik sonrasında tartışma soruları sorularak öğrencilerin görüşleri alınmıştır. Grup kuralları oturum esnasında grup üyeleri tarafından belirlenmiş ve eksik kalan yerlerde grup lideri bilgi paylaşımında bulunmuştur. Grup üyelerinin kendi amaçlarını belirtebilmeleri için bazı sorular sorulmuş ve üyelerin yanıtlarını yazmaları istenmiştir. "Uzayı Hayal Eden Çocuk" formu grup üyelerine dağıtılmış ve grup üyelerinin formda belirtilen soruyu yanıtlamaları istenmiştir. Daha sonra yanıtlar üzerinde durulmuştur. Oturum, grup lideri tarafından özetlenmiş ve sonlandırılmıştır. Gelecek hafta ne üzerinde durulacağı hakkında bilgi verilmiş ve ev ödevi verilmiştir. Değerlendirme 1 formunu grup üyelerinin doldurmaları sağlanmış ve iyi dileklerle grup oturumu tamamlanmıştır.

2. Oturumda, grup üyelerinin etkili iletişimin önemini fark etmesi amaçlanmıştır. Öncelikle, bir önceki oturum kısaca hatırlatılmış ve grup üyelerinin ev ödevleri üzerinde durulmuştur. İletişimin ve etkili iletişimin ne olduğu grup üyelerine sorulmuş ve yanıtları alınmıştır. Grup üyelerinden yanitlar alındıktan sonra, grup lideri tarafından iletişim ve etkili iletişim üzerine kısaca bilgi verilmiştir. Etkili iletişimin öneminin fark edilmesi için "Sırt Sırta" etkinliği yapılmıştır. Etkinlik sonrası tartışma soruları sorulmuş ve grup üyelerinin görüşleri alınmıştır. İletişim engelleri üzerinde durulmuş, grup üyelerinin görüşleri alındıktan sonra bazı iletişim engelleri üzerine bilgi verilmiştir. Oturum, grup lideri tarafından özetlenmiş ve sonlandırılmıştır. Gelecek hafta ne üzerinde durulacağı hakkında bilgi verilmiş ve ev ödevi 
verilmiştir. Değerlendirme 2 formunu grup üyelerinin doldurmaları sağlanmış ve iyi dileklerle grup oturumu tamamlanmıştır.

3. Oturumda, grup üyelerinin kendilerini daha iyi tanıması amaçlanmıştır. Öncelikle, bir önceki oturum kısaca hatırlatılmış ve grup üyelerinin ev ödevleri üzerinde durulmuştur. Kendini tanımanın önemine yönelik grup lideri tarafından giriş yapılmıştır. Daha sonra tartışma soruları ile grup üyelerinin görüşleri alınmıştır. "Vivaldi - Dört Mevsim" müziği eşliğinde gözünde canlandırma etkinliği yapılmıştır. Grup üyelerinden, verilen renkli kâğıtlara ellerini çizmeleri ve çizimlerine kendi özelliklerini yazmaları istenmiştir. Tartışma soruları sorularak grup üyelerinin görüşleri alınmıştır. Daha sonra ikili gruplar oluşturulmuş ve gruplara “Ortak Özelliklerimiz" formu dağıtılmıştır. Verilen forma öncelikle kendi özelliklerini ardından, ortak özelliklerini yazmaları istenmiştir. Tartışma soruları sorularak grup üyelerinin görüşleri alınmıştır. Yürüyüş etkinliği yapılarak grup oturumu sonlandırılmıştır. Gelecek hafta ne üzerinde durulacağı hakkında bilgi verilmiş ve ev ödevi verilmiştir. Değerlendirme 3 formunu grup üyelerinin doldurmaları sağlanmış ve iyi dileklerle grup oturumu tamamlanmıştır.

4. Oturumda kendilerine ve çevrelerine yönelik farkındalık kazanmak ve güçlü/zayıf yönlerini görmek amaçlanmıştır. Öncelikle, bir önceki oturum kısaca hatırlatılmış ve grup üyelerinin ev ödevleri üzerinde durulmuştur. İnsanların güçlü yanlarının olabileceği gibi zayıf yanlarının da olabileceği belirtilmiş ve farklılıklara saygı duymanın önemine grup lideri tarafından giriş yapılmıştır. "Güçlü ve Zayıf Yönlerim" formu grup üyelerine dağıtılmış ve bulutların birine güçlü diğerine zayıf özelliklerini yazmaları istenmiştir. Daha sonra tartı̧̧ma soruları sorularak grup üyelerinin görüşleri alınmıştır. Verilen forma bir dinozor resmi çizmeleri istenmiş ve grup üyelerinin rahatlamaları sağlanmıştır. Farklı kişilerinde güçlü ve zayıf yönlerinin olacağının görülmesi için "Güçlü ve Zayıf Yönler" formu dağıtılmış ve verilen hikâyeleri istenilen şekilde tamamlamaları istenmiştir. Etkinlik sonrasında tartışma soruları sorularak grup üyelerinin görüşleri alınmıştır. Grup üyelerinin potansiyellerini etkin kullanmalarına yönelik güçlü özellikleri üzerinde durulmuş ve tartışma soruları sorularak görüşleri alınmıştır. Oturum, grup lideri tarafından özetlenmiş ve 
sonlandırılmıştır. Gelecek hafta ne üzerinde durulacağı hakkında bilgi verilmiş ve ev ödevi verilmiştir. Değerlendirme 4 formunu grup üyelerinin doldurmaları sağlanmış ve iyi dileklerle grup oturumu tamamlanmıştır.

5. Oturumda grup üyelerinin duygularını tanıması ve duygularını fark etmesi amaçlanmıştır. Öncelikle, bir önceki oturum kısaca hatırlatılmış ve grup üyelerinin ev ödevleri üzerinde durulmuştur. Daha sonra grup üyelerine "Şuan kendinizi nasıl hissediyorsunuz?" sorusu sorulmuştur. Gelen yanitlardan sonra "Duygu Listesi" grup üyelerine dağıtılmış, incelemeleri sağlanmış ve aslında yaşamda duyguların ne kadar çok olduğu belirtilmiştir. Bunun üzerine tartışma soruları sorulmuş ve grup üyelerinin görüşleri alınmıştır. Daha sonra öğrencilere daire şeklinde kesilmiş renkli kâğıtlar verilmiş ve duygu listesindeki olumlu ve olumsuz duygulardan 5'er tane yazmaları istenmiş ve ardından olumlu/olumsuz duygular üzerine durulmuştur. "Hangi Duyguları Ne Zaman Yaşarsınız?" formu grup üyelerine dağıtılmış ve 5 dakika süre verilmiştir. Etkinlikle ilgili tartışma soruları sorularak grup üyelerinin görüşleri alınmıştır. Sonlandırma etkinliği olarak köpük balon oyunu oynanmıştır. Oturum, grup üyeleri tarafından özetlenmiş ve sonlandırılmıştır. Gelecek hafta ne üzerinde durulacağı hakkında bilgi verilmiş ve ev ödevi verilmiştir. Değerlendirme 5 formundaki bulmacay 1 grup üyelerinin tamamlamaları sağlanmış ve iyi dileklerle grup oturumu tamamlanmıştır.

6. Oturumda, duyguların yaşamdaki önemini görmek ve ifade etmek amaçlanmıştır. Öncelikle, bir önceki oturum kısaca hatırlatılmış ve grup üyelerinin ev ödevleri üzerinde durulmuştur. Duyguları ifade etmenin önemi üzerine grup lideri tarafından giriş yapılmıştır. Grup üyelerine "Ne Hissederim ve Ne Söylerim" formu dağıtılmıştır. İlk olarak ne hissederim bölümünü ve sonrasında ne söylerim bölümünü doldurmaları sağlanmıştır. Etkinlikle ilgili tartışma sorusu sorularak grup üyelerinin görüşleri alınmıştır. Diğer kişilerin duygularının da önemli olduğu belirtilerek empati üzerinde durulmuştur. Tartışma soruları sorularak empati ve duyguları ifade etmeyle ilgili grup üyelerinin görüşleri alınmıştır. Sonlandırma etkinliği olarak film kesiti oyunu oynanmıştır. Grup üyelerine, birer duygu kartı verilmiş ve kendinden önceki kişinin hikâyesini elindeki duygu ifadesine uygun 
şekilde devam ettirmesi istenmiştir. Ortak çıkan hikâye grup ortamında grup lideri tarafından okunmuştur. Oturum, grup üyeleri tarafından özetlenmiş ve sonlandırılmıştır. Gelecek hafta ne üzerinde durulacağ1 hakkında bilgi verilmiş ve ev ödevi verilmiştir. Değerlendirme 6 formunu grup üyelerinin doldurmaları sağlanmış ve iyi dileklerle grup oturumu tamamlanmıştır.

7. Oturumda, sosyal izolasyonu azaltmak ve arkadaş ilişkilerinin önemini fark etmek amaçlanmıştır. Öncelikle, bir önceki oturum kısaca hatırlatılmış ve grup üyelerinin ev ödevleri üzerinde durulmuştur. Grup lideri tarafından arkadaşlık üzerine tartışma soruları sorularak grup üyelerinin görüşleri alınmıştır. Grup üyelerine "Yonca" formu dağıtılmış ve bir arkadaşta bulunması gereken 4 özelliği yazmaları istenmiştir. Etkinlikle ilgili tartışma soruları sorularak grup paylaşımı yapılmıştır. Yeni arkadaş edinirken nelere dikkat edilmesi gerektiği üzerinde durulmuş ve tartışma soruları ile grup üyelerinin görüşleri alınmıştır. Ardından grup üyelerinden ikili gruplar oluşturulmuş ve senaryo kartları dağıtılmıştır. Rol oynama tekniği ile etkinlik yürütülmüş ve tartışma soruları sorularak grup paylaşımı yapılmıştır. Oturum, grup üyeleri tarafından özetlenmiş ve sonlandırılmıştır. Gelecek haftanın son oturum olduğu belirtilmiş, ne üzerinde durulacağı hakkında bilgi verilmiş ve ev ödevi verilmiştir. Değerlendirme 7 formunu grup üyelerinin doldurmaları sağlanmış ve iyi dileklerle grup oturumu tamamlanmıştır.

8. Oturumda problem çözme becerileri, stresle baş etme becerileri ve tüm oturumların değerlendirmesi ele alınmıştır. Öncelikle, bir önceki oturum kısaca hatırlatılmış ve grup üyelerinin ev ödevleri üzerinde durulmuştur. İlk olarak kişilerarası ilişkilerde problem çözmenin önemine değinilmiş ve tartışma soruları sorularak grup paylaşımı yapılmıştır. Daha sonra stresin tanımı yapılmış ve etkisine yönelik grup üyelerine bilgi verilmiştir. Bu konuda, tartışma soruları sorularak grup üyelerinin görüşleri alınmıştır. Grup üyelerinden grup oturumlarını değerlendirmeleri istenmiştir. Grup üyelerine "Hedeflerim" formu dağıtılarak son oturumda hedeflerini yeniden yazmaları ve sorumluluğunu almaları konusunda cesaretlendirme yapılmıştır. Tartışma soruları sorularak grup paylaşımı yapılmıştır. Tüm oturumların kısaca özetleri yapılmış ve grup oturumları tamamlanmıştır. 


\section{Kaynakça Bilgisi / Citation Information}

Sevgili Koçak, S. ve Kan, A. (2021).Üstün yetenekli çocukların sosyal duygusal gelişimlerine yönelik geliştirilen psiko-eğitim programının etkisi. OPUS-Uluslararası Toplum Araştırmaları Dergisi, 18(44), 8054-8091. DOI: 10.26466/opus.931746. 